\title{
Modeling asymmetric price transmission in the European food market
}

\begin{abstract}
In this study, we employ a multivariate panel error correction model (PVECM) to investigate asymmetric price transmission among the farm, processor and retail segments of the food supply chain and its components (cereals and bread; meat; milk, cheese and eggs; and oils and fat) at the EU-28 level and at EU country-specific level for the 2005 - 2016 period. The results indicate that, in both the long- and short-run, processor (retail) prices respond more strongly to farm (processor) price increases than decreases. Thus, the findings demonstrate the presence of positive asymmetric price transmission in the European food supply chain (and its components) at the EU-28 level and at the country-specific level. Positive long-run price transmission asymmetry can be attributed to the strong market power of the European food retailers over processors and, in turn, that of processors over farmers. The short-run asymmetric price transmission can be caused by factors, such as adjustment and menu costs, search costs, inventory management strategies and policy intervention, among others. Finally, the results of the present study indicate that the food price pass-through varies greatly across product category and across counties, and that the pass-through to producer prices is greater than that to consumer prices.
\end{abstract}

Key Words: Multivariate panel vector error correction models, Asymmetric price transmission, European food supply chain

JEL Classifications: Q11, C50, C13 


\section{Introduction}

The food supply chain is composed of a wide variety of goods and enterprises functioning in various markets and selling diverse agricultural and food products (Bukeviciute et al., 2009). The food supply chain combines three main sectors (the agricultural sector, the food processing industry and the retailing sector), which are linked together via the price mechanism. The extent of price transmission through the production, processing and retailing markets, as well as the relation between farm prices, producer (i.e. processor) prices and consumer (i.e. retail) food prices are matters of considerable interest. ${ }^{1}$ One issue that is of particular importance is whether price increases and decreases at one level of the food supply chain have asymmetric effects (i.e. are transmitted differently with regard to magnitude) on the downstream levels. The present study investigates asymmetric price transmission in the European food supply chain during the period 2005 - 2016. The study focuses on the relationship between farm, producer (i.e. processor) and consumer (i.e. retail) prices using, first, an aggregate index (at the EU-28 level) of "food" commodity prices and its four individual subcomponents of this index (cereals and bread; meat; milk, cheese and eggs; and oils and fat) and, second, country-specific data for the aggregate index of "food" commodity prices and its four individual subcomponents.

As indicated in Figure 1, farm prices show severe fluctuations, especially after the year 2007. In particular, farm prices present increasing trends during the $2007-2008$ and 2010 - 2012 time periods, reaching high levels during the final year of each of the periods mentioned above, while they show decreasing trends during the year 2009 and

\footnotetext{
${ }^{1}$ The terms 'producer' and 'processors' are used interchangeably in the manuscript. The same for the terms 'consumer' and 'retailer'.
} 
the 2013 - 2014 period, reaching low levels by the middle of 2009 and the end of 2014 . However, over the same period, the fluctuations in the food producer and consumer prices are much smoother, to the extent that farm prices, food producer prices and consumer prices show diverging trends. This indicates that farm price fluctuations are not transmitted proportionally to food producer and consumer prices, which to a certain extent is expected, since the cost of the agricultural product constitutes only a small share of the total cost of the final consumer food product. For some food supply chains (e.g. wheat to bread - Figure 2 - and oils and fats - Figure 5), consumer prices appear to rise in response to agricultural commodity and raw material price increases, but consumer prices tend to be sticky and often fail to follow suit when the prices for agricultural commodities and raw materials fall (EC, 2015). This phenomenon is known as asymmetric price transmission. For some other supply chains (e.g. fruits and vegetables), however, no firm conclusions can be drawn about the presence of asymmetric price transmission (EC, 2015). Thus, the main purpose of the present study is to investigate the possible existence of asymmetric price transmission in the food supply chain and its components (cereals and bread; meat; milk, cheese and eggs; and oils and fat) at the EU-28 level and at EU country-specific level. To achieve this, we used a multivariate panel vector error correction model (PVECM) which is estimated according to monthly datasets created by aggregate and disaggregate price index observations of the farm, food processing and food consumption levels at the EU-28 level and at EU country-specific level. Datasets were obtained from the recently developed Food Prices Monitoring Tool, while data availability constrained the analysis at the disaggregated, as well as the country-specific, levels. According to Peltzman (2000), if consumer prices react more fully or rapidly to an 
increase (decrease) in farm prices than to a decrease (increase), the asymmetry is classified as 'positive' ('negative').

An additional contribution of the study is that it examines asymmetric price transmission at the EU-28 level and EU country-specific level using aggregated and disaggregated food data. Furthermore, the present study involves the examination of several findings reported in the existing literature (Ferrucci et al., 2010), such as whether: (i) the food price pass-through varies greatly across product category, (ii) the food price pass-through differs across counties, and (iii) the pass-through from farm to producer (i.e. processor) prices is higher than from producer to consumer (i.e. retail) prices.

A large number of empirical studies have been conducted on price transmission along agri-food supply chains (Wolffram, 1971; Houck, 1977; Ward, 1982; Kinnucan and Forker, 1987; von Cramon-Taubadel and Fahlbusch, 1994; Zhang et al., 1995; Goodwin and Harper, 2000; Tiffin and Dawson, 2000; Abdulai, 2002; Serra and Goodwin, 2003; Lass, 2005; Ben-Kaabia and Gil, 2007; Gervais, 2011; Rezitis and Reziti, 2011; Fousekis et al., 2016). Price transmission has been an important topic in agricultural economics research for almost 50 years because of the extent to which shocks are transmitted along the food supply chain, which have potentially important welfare and policy implications for market participants. Three different surveys (Meyer and von Cramon-Taubadel, 2004; Vavra and Goodwin, 2005; Frey and Manera, 2007) have presented a review of the empirical studies on asymmetric price transmission in commodity markets. Meyer and von Cramon-Taubadel (2004) categorized the econometric methods employed to identify the presence of asymmetric price transmission into pre-cointegration models and 
cointegration-based approaches. ${ }^{2}$ Pre-cointegration techniques were mainly used in early studies on asymmetric price transmission (Capps and Sherwell, 2007; Houck, 1977; Kinnucan and Forker, 1987; Lass, 2005; Ward, 1982; Wolffram, 1971), but they involved some shortcomings by ignoring the problems associated with non-stationary time series data. Studies using error correction models (ECM) allowed for asymmetric price adjustments by distinguishing between positive and negative shocks to error correction terms in examining asymmetric price transmission in food markets. Among the first studies on food markets to use the ECM were those by von Cramon-Taubadel and Fahlbusch (1994), von Cramon-Taubadel (1998) and von Cramon-Taubadel and Loy (1999). Further studies on asymmetric ECMs employed the threshold error correction model (TECM) to take into consideration the potential for non-linear and threshold-type adjustment in ECMs in cases where larger shocks cause a different response than smaller shocks. Among the first to apply the TECM to examine asymmetric price transmission in food markets were Goodwin and Holt (1999), Goodwin and Harper (2000), Goodwin and Piggott (2001) and Ben-Kaabia and Gil (2007).

The existing studies on price transmission in food markets suffered from two major limitations. First, many of the empirical studies described above focused on the investigation of agri-food price asymmetry expressed in a linear form. However, the estimation of the model dynamics is severely jeopardized when a non-linear long-run relationship is misspecified as linear (Greenwood-Nimmo and Shin, 2013; Shin et al., 2013). Second, many previous empirical and theoretical asymmetric adjustment models have been constructed under the assumption of treating regression functions identically

${ }^{2}$ It is worth mentioning that, recently, there have been a number of studies on the price transmission topic using a copula-based statistical approach, among such studies are Fousekis and Grigoriadis (2017) and Panagiotou and Stavrakoudis (2015). 
across all the observations in their sample, not allowing them to fall into discrete classes. However, this premise is not credible. Instead we develop and perform likelihood-based analysis in the context of a full panel vector autoregressive model, allowing for asymmetries in the cointegrating equations and the long-run dynamics. Therefore, this paper, for the first time in the food price asymmetry controversy, develops econometric techniques for multivariate panel vector error correction models (PVECMs) and proposes new statistical inference techniques.

The importance of the EU food supply chain to the EU economy involves many economic and social aspects. Based on EC (2015), agricultural producers and the food processing industry jointly accounted for about $7.5 \%$ of the total employment in the EU and $3.7 \%$ of the EU's total value added in 2011. Furthermore, the food processing industry is the biggest among the EU industries, accounting for about $13 \%$ of the total industrial EU gross value added and $15 \%$ of the total employment in the EU industrial sector in 2011. Food and beverage spending accounted for about 14\% in 2013 at the EU level, and it is the second biggest expense of household budgets after housing. The EU food supply chain includes more than 15.5 million holdings (enterprises), which are involved in the agricultural sector, the food processing industry and the retailing and service sectors. The percentage of enterprises in the whole food supply chain engaged in agriculture is high $(80 \%)$, but the share of value added by the agricultural sector to the whole food supply chain is much lower $(25 \%)$. While most of the enterprises in all stages of the food chain are small- or medium-sized, the concentration in the food processing and retailing sectors is much greater than in the agricultural sector. Based on EUAMB (2014), the C5 concentration ratio of the food processing industry (retailing sector) in 14 
(13) EU member states was $56 \%(60 \%)$ in 2012 . However, the C5 concentration ratio of the agricultural sector at the EU level in 2010 accounted for only $0.19 \%$, indicating that farmers tend to have weaker negotiating power in the food supply chain than food processors and retailers (EC, 2014).

The remainder of this paper is organized as follows. The following section describes the econometric model, while the subsequent two sections report the data set used for the analysis and the empirical results and discussion, respectively. The final section concludes the paper.

\section{Econometric model}

This paper considers nonlinear threshold PVECMs and proposing Markov chain Monte Carlo (MCMC) techniques to perform Bayesian inference with significant contribution in the modeling framework employed. Specifically, this paper extends Greenwood-Nimmo and Shin (2013) to a panel data framework and a system-of-equations framework. The model is as follows. Suppose we have an asymmetric long-run relationship of the form:

$$
\mathrm{y}_{\mathrm{it}}=\mu_{\mathrm{i}}+\mathrm{x}_{\mathrm{it}}^{\mathrm{\prime}^{\prime}} \boldsymbol{\alpha}^{+}+\mathrm{x}_{\mathrm{it}}^{-^{\prime}} \boldsymbol{\alpha}^{-}+\mathrm{u}_{\mathrm{it}}, \forall \mathrm{i}=1, \ldots, \mathrm{n}, \mathrm{t}=1, \ldots, \mathrm{T}
$$

where $\mu_{i}$ represents fixed effects, $\mathbf{x}_{i t}$ is a $k \times 1$ vector of regressors, $\mathbf{x}_{\mathrm{it}}^{+}=\sum_{\mathrm{j}=1}^{\mathrm{t}} \max \left(\Delta \mathbf{x}_{\mathrm{ij}}, \lambda\right), \mathbf{x}_{\mathrm{it}}^{-}=\sum_{\mathrm{j}=1}^{\mathrm{t}} \min \left(\Delta \mathbf{x}_{\mathrm{ij}}, \lambda\right)$ are partial sum processes representing changes that exceed or are below a threshold $\lambda$, respectively. We have the following conditional Panel Vector-Error-Correction Model (PVECM): 


$$
\begin{aligned}
\Delta y_{i t}= & \mu_{i}+\rho y_{i, t-1}+\delta^{+\prime} \mathbf{x}_{i, t-1}^{+}+\delta^{-{ }^{\prime}} \mathbf{x}_{i, t-1}^{-}+\sum_{j=1}^{p-1} \gamma_{j} \Delta y_{i, t-j}+ \\
& \sum_{j=0}^{q-1}\left(\pi_{j}^{+\prime} \Delta \mathbf{x}_{i, t-j}^{+}+\pi_{j}^{-\prime} \Delta \mathbf{x}_{i, t-j}^{-}\right)+e_{i t}
\end{aligned}
$$

A stable long-run relationship requires $\rho \neq 0$ or, alternatively, $\left(\rho=0, \boldsymbol{\delta}^{+}=\boldsymbol{\delta}^{-}\right)$not all zero. Short-run symmetry requires the following two strong and weak forms, respectively:

$$
\pi_{j}^{+}=\pi_{j}^{-}, \forall j=0, \ldots, q-1,(\text { pair-wise or strong form) }
$$

or alternatively:

$$
\sum_{j=0}^{\mathrm{q}-1} \pi_{\mathrm{j}}^{+}=\sum_{\mathrm{j}=0}^{\mathrm{q}-1} \boldsymbol{\pi}_{\mathrm{j}}^{-} \text {(additive or weak form). }
$$

Following Greenwood-Nimmo and Shin (2013), we focused on the less restrictive additive case (i.e. weak form of asymmetry), but we also evaluated the symmetry of the pair-wise form (i.e. strong form of asymmetry). This was the model used by GreenwoodNimmo and Shin (2013) and Shin, et al. (2013). However, the model was extended as we wished to examine a system of equations following the usual order: farm prices, producer prices, consumer prices. In several studies (Kinnucan and Forker, 1987; Lass, 2005; Gervais, 2011), it is usually assumed that the price is first determined at the farm level and then is transmitted to the downstream levels (i.e., wholesale, processing and retail levels). A common justification for this assumption is that supply shocks are more frequent than the demand stocks and that retailers incorporate a fixed mark-up pricing strategy. Furthermore, a large body of empirical research appears to support unidirectional price transmission from the farm to downstream markets (Abdulai, 2002; 
Goodwin and Piggott, 2001; Fousekis et al., 2016). Therefore, in (1) and (2) $y_{i t}$ is a vector that contains i) producer prices and $\mathbf{x}_{i t}$ contains farm prices, ii) consumer prices and $\mathbf{x}_{i t}$ contains producer prices. The two equations have an error contemporaneous correlations matrix. In the subsequent discussion, we present the model using a simplified notation, as far as possible.

For a more general specification, we assume that (i) long-run and short-run coefficients can be country-specific and (ii) error terms can be cross-sectionally correlated. The extended model has the following form:

$$
\mathrm{y}_{\mathrm{it}}=\mu_{\mathrm{i}}+\mathbf{x}_{\mathrm{it}}^{+\prime} \boldsymbol{\alpha}_{\mathrm{i}}^{+}+\mathbf{x}_{\mathrm{it}}^{-\prime} \boldsymbol{\alpha}_{\mathrm{i}}^{-}+\mathrm{u}_{\mathrm{it}}, \forall \mathrm{i}=1, \ldots, \mathrm{n}, \mathrm{t}=1, \ldots, \mathrm{T},
$$

with the following short-run nonlinear ECM:

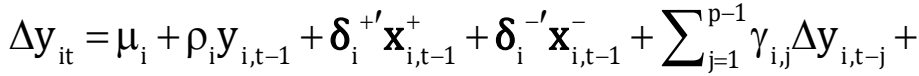

$$
\begin{aligned}
& \sum_{\mathrm{j}=0}^{\mathrm{q}-1}\left(\boldsymbol{\pi}_{\mathrm{i}, \mathrm{j}}{ }^{\prime} \Delta \mathbf{x}_{\mathrm{i}, \mathrm{t}-\mathrm{j}}^{+}+\boldsymbol{\pi}_{\mathrm{i}, \mathrm{j}}{ }^{-{ }^{\prime}} \Delta \mathbf{x}_{\mathrm{i}, \mathrm{t}-\mathrm{j}}^{-}\right)+\varepsilon_{\mathrm{it}} \text {, }
\end{aligned}
$$

Moreover,

$$
\mathbb{E}\left(\varepsilon_{i t} \varepsilon_{j \tau}\right)=\left\{\begin{array}{l}
\sigma_{i j}, \quad t=\tau \\
0, \text { otherwise }
\end{array}\right.
$$

Suppose:

$$
\boldsymbol{\beta}_{\mathrm{i}}=\left[\rho_{\mathrm{i}}, \boldsymbol{\delta}_{\mathrm{i}}^{+^{\prime}}, \boldsymbol{\delta}_{\mathrm{i}}^{\mathbf{\prime}^{\prime}},\left(\gamma_{\mathrm{i}, \mathrm{j}}, \mathrm{j}=1, \ldots, \mathrm{p}-1\right),\left(\pi_{\mathrm{i}, \mathrm{j}}^{+}, \pi_{\mathrm{i}, \mathrm{j}}^{-}, \mathrm{j}=0, \ldots, \mathrm{q}-1\right)\right]^{\prime} \in \mathbb{R}^{\mathrm{K}},
$$

for $i=1, \ldots, n$. For the coefficients $\boldsymbol{\beta}_{\mathrm{i}}$ we assume: 


$$
\boldsymbol{\beta}_{\mathrm{i}} \sim \mathcal{N}_{\mathrm{K}}(\bar{\beta}, \Omega), \mathrm{i}=1, \ldots, \mathrm{n}
$$

For the error terms we assume:

$$
\boldsymbol{\varepsilon}_{\mathrm{i}}=\left[\varepsilon_{\mathrm{i} 1}, \ldots, \varepsilon_{\mathrm{iT}}\right]^{\prime \mathrm{iid}} \sim \mathcal{N}_{\mathrm{T}}(\mathbf{0}, \boldsymbol{\Sigma})
$$

independently of all regressors and other stochastic elements of the model.

Given the considerable amount of heterogeneity that we have allowed for, the assumption of a general covariance matrix, $\boldsymbol{\Sigma}=\left[\sigma_{\mathrm{ij}}, \mathrm{i}, \mathrm{j}=1, \ldots, \mathrm{n}\right]$ is, perhaps, excessive but we retain it for generality.

Suppose $\Delta \mathrm{y}_{\text {it }}=\mathrm{w}_{\text {it }}$ so that the model can be written as a nonlinear VAR with regressors:

$$
\begin{gathered}
\mathrm{w}_{\mathrm{it}}=\sum_{\mathrm{j}=1}^{\mathrm{p}-1} \gamma_{\mathrm{i}, \mathrm{j}} \mathrm{w}_{\mathrm{i}, \mathrm{t}-\mathrm{j}}+\rho_{\mathrm{i}} \mathrm{y}_{\mathrm{i}, \mathrm{t}-1}+\boldsymbol{\delta}_{\mathrm{i}}^{+{ }^{\prime}} \mathbf{x}_{\mathrm{i}, \mathrm{t}-1}^{+}+\boldsymbol{\delta}_{\mathrm{i}}^{{ }^{\prime} \mathbf{x}_{\mathrm{i}, \mathrm{t}-1}^{-}}+ \\
\sum_{\mathrm{j}=0}^{\mathrm{q}-1}\left(\boldsymbol{\pi}_{\mathrm{i}, \mathrm{j}}{ }^{\prime} \Delta \mathbf{x}_{\mathrm{i}, \mathrm{t}-\mathrm{j}}^{+}+\boldsymbol{\pi}_{\mathrm{i}, \mathrm{j}}{ }^{-\prime} \Delta \mathbf{x}_{\mathrm{i}, \mathrm{t}-\mathrm{j}}^{-}\right)+\varepsilon_{\mathrm{it}}
\end{gathered}
$$

from which we obtain:

$$
\mathrm{w}_{\mathrm{it}}=\sum_{\mathrm{j}=1}^{\mathrm{p}-1} \gamma_{\mathrm{i}, \mathrm{j}} \mathrm{w}_{\mathrm{i}, \mathrm{t}-\mathrm{j}}+\mathbf{z}_{\mathrm{it}}^{\prime} \boldsymbol{\xi}_{\mathrm{i}}+\varepsilon_{\mathrm{it}} \equiv \mathbf{x}_{\mathrm{it}}^{\prime} \boldsymbol{\beta}_{\mathrm{i}}+\varepsilon_{\mathrm{it}}
$$

where $\xi_{i}=\left[\boldsymbol{\delta}_{i}^{+\prime}, \boldsymbol{\delta}_{i}^{-\prime},\left(\gamma_{i, j}, j=1, \ldots, p-1\right),\left(\pi_{i, j}{ }^{+}, \boldsymbol{\pi}_{i, j}^{-}, j=0, \ldots, q-1\right)\right]^{\prime}$, viz. all elements of $\boldsymbol{\beta}_{i}$ except $\rho_{\mathrm{i}}$.

In a Bayesian treatment of the problem, we have to address the following issues:

(i) The determination of lag orders $p$ and $q$. 
(ii) The determination of an informative prior for $\overline{\boldsymbol{\beta}}$ which, however, is not as highdimensional as unrestricted coefficients would be in a general Bayesian VAR.

(iii) The determination of a prior for $\boldsymbol{\Sigma}$ and $\boldsymbol{\Omega}$.

(iv) A computational strategy to implement Markov chain Monte Carlo (MCMC) for full Bayesian inference.

Problem (i) is relatively easy as we can implement model comparison via marginal likelihood and Bayes' factors (see our discussion in subsection 4.1 Model selection). Regarding (ii), we can assume simply that $\overline{\boldsymbol{\beta}}=\mathbf{0}_{K}$ but (as part of the problem (iii)) we have to choose a reasonable prior for $\boldsymbol{\Omega}$. Given the Cholesky decomposition $\mathbf{\Omega}=\mathbf{C}^{\prime} \mathbf{C}$ and the unique elements $c_{i j}$ of the lower triangular matrix , we assume:

$$
\mathrm{c}_{\mathrm{ij}} \sim \mathcal{N}(0,1), \forall \mathrm{j} \leq \mathrm{i}, \mathrm{i}=1, \ldots, \mathrm{n}
$$

For matrix $\boldsymbol{\Sigma}$, we assume a single-factor model based on the point that we made above. Specifically:

$$
\varepsilon_{t}=\varphi f_{t}+v_{t}
$$

where $\varepsilon_{\mathrm{t}}=\left[\varepsilon_{\mathrm{t} 1}, \ldots, \varepsilon_{\mathrm{tn}}\right]^{\prime}$, the common factor:

$$
\mathrm{f}_{\mathrm{t}}=\mathrm{af}_{\mathrm{t}-1}+\mathrm{e}_{\mathrm{t}}, \mathrm{e}_{\mathrm{t}}^{\mathrm{iid}} \sim \mathcal{N}\left(0,1-\mathrm{a}^{2}\right)
$$


provided $|a|<1$. The formulation guarantees that (in the stationary case) the expected value of $f_{t}$ is zero and its variance is equal to one.

Additionally, we assume: $\mathbf{v}_{\mathrm{t}} \sim \mathcal{N}_{\mathrm{n}}\left(\mathbf{0}, \operatorname{diag}\left[\omega_{1}^{2}, \ldots, \omega_{\mathrm{n}}^{2}\right]\right)$ and $\boldsymbol{\varphi}$ is an $n \times 1$ vector of factor loadings. As our prior opinion is that cross-sectional correlations are similar, and to avoid the proliferation of parameters, we assume:

$$
\varphi_{1}=\ldots=\varphi_{\mathrm{n}}=\varphi
$$

Moreover, we assume:

$$
\mathbf{v}_{\mathrm{t}}^{\mathrm{iid}} \sim \mathcal{N}_{\mathrm{n}}\left(\mathbf{0}, \operatorname{diag}\left[\sigma_{1}^{2}, \ldots, \sigma_{\mathrm{n}}^{2}\right]\right)
$$

We enforce parsimony by assuming:

$$
\log \sigma_{\mathrm{i}}^{2} \mid \sigma_{1}^{2} \sim \mathcal{N}\left(\log \sigma_{1}^{2}, \vartheta^{2}\right), \forall \mathrm{i}=2, \ldots, \mathrm{n}, \log \sigma_{1}^{2} \sim \mathcal{N}\left(\overline{\mathrm{a}}_{1}, \overline{\mathrm{a}}_{2}^{2}\right)
$$

We set $\vartheta=0.4, \bar{a}_{1}=-3, \bar{a}_{2}=0.1$. The resulting prior for $\sigma_{1}$ averages 0.23 with a standard deviation of 0.034 . The typical ratio $\sigma_{i} / \sigma_{1}, i \neq 1$ averages 1.06 and its $95 \%$ credible (Bayes) interval is from 0.69 to 1.70 .

For parameter a in (14) we assume:

$$
\mathrm{p}(\mathrm{a}) \propto \mathbb{I}(-1<\mathrm{a}<1) .
$$

\section{Data}


Table 1 presents the six different data sets used in the empirical investigation of asymmetric price transmission of the European food market for period 2005:01-2016:09. The first dataset consists of monthly price indices (2005:01-2016:09, with $2010=100$ ) for the farm (i.e. agricultural commodity), producer (i.e. processor) and consumer (i.e. retail) segments of the food supply chain and its four subcomponents (cereals and bread; meat; milk, cheese and eggs; and oils and fats) at the EU-28 level. Thus, the first dataset consists of a panel of five indices (food; cereals and bread; meat; milk, cheese and eggs; and oils and fat) for each segment of the supply chain (farm, processor and retail). The other five datasets consist of country-specific panels of monthly price indices (2005:012016:09, with $2010=100$ ) of food and its four above-mentioned subcomponents of the three stages of the food supply chain (farming, processing and retailing). The countryspecific panel datasets on farm, producer and consumer price indices for the "food", "cereal and bread", "meat", "milk, cheese and eggs" and "oils and fat" supply chains represent 23, 12, 14, 10 and $8 \mathrm{EU}$ countries, respectively. The inclusion of European countries in the datasets was based on data availability. The data sets were acquired from the Food Price Monitoring Tool of Eurostat ${ }^{3}$ (as viewed on 4 July 2017). Unit root tests results show that all price series are $\mathrm{I}(1)$ in levels and $\mathrm{I}(0)$ in their first differences.

Table 1 provides the calculated mean statisitcs on farm, producer (i.e. processor) and consumer (i.e. retail) price indices of the aggregate food supply chain and its four components (cereals and bread; meat; milk, cheese and eggs; and oils and fats) for the EU-28 and for specific EU member states.

\footnotetext{
${ }^{3}$ http://ec.europa.eu/eurostat/web/hicp/methodology/food-price-monitoring-tool
} 


\section{Empirical results and discussion}

\subsection{Model selection}

For model selection (values of $p$ and $q$ ), we rely on the computation and comparison of marginal likelihoods and Bayes' factors. The Bayes' factors were computed using marginal likelihoods for threshold PVECM models (see the Appendix). We normalized the Bayes' factor to 1 for $p=2, q=1$, the simplest possible model in our context. Suppose $\mathbb{Y}$ denotes the available data and $\theta \in \Theta \subseteq \mathbb{R}^{\mathrm{D}}$ is the vector of parameters. For any posterior distribution whose kernel $^{4}$ is:

$$
\mathrm{p}(\theta \mid \mathbb{Y}) \propto \mathcal{L}(\theta ; \mathbb{Y}) \mathrm{p}(\theta)
$$

where $\mathcal{L}(\theta ; \mathbb{Y})$ is the likelihood function and $p(\theta)$ is the prior, the marginal likelihood can be expressed as:

$$
\mathfrak{M}(\mathbb{Y})=\int \mathcal{L}(\theta ; \mathbb{Y}) \mathrm{p}(\theta) \mathrm{d} \theta
$$

The posterior itself is:

$$
\mathrm{p}(\theta \mid \mathbb{Y}) \propto \frac{\mathcal{L}(\theta ; \mathbb{Y}) \mathrm{p}(\theta)}{\int_{\Theta} \mathcal{L}(\theta ; \mathbb{Y}) \mathrm{p}(\theta) \mathrm{d} \theta}=\frac{\mathcal{L}(\theta ; \mathbb{Y}) \mathrm{p}(\theta)}{\mathfrak{M}(\mathbb{Y})}
$$

Similarly, we can define the marginal likelihood:

$$
\mathfrak{M}(\mathbb{Y})=\int \mathcal{L}(\theta ; \mathbb{Y}) \mathrm{p}(\theta) \mathrm{d} \theta
$$

\footnotetext{
4 "Kernel" means that the normalizing constant is omitted. In most circumstances this is because it is not available in closed form.
} 
Based on the results of Table 2, we selected a model with $p=4$ and $q=4$ which is strongly favored over the other alternatives.

\subsection{Empirical results and discussion}

The core of studies analyzing the relationship between food consumer and farm prices is the examination of short- and long-run asymmetries. A short-run analysis compares the changes in food price variations to positive and negative farm price changes, while a long-run analysis concentrates on the speed of adjustment towards an equilibrium level (Frey and Manera, 2007). This study used a PVECM to decompose the food processing (producer) and retailing (consumer) price fluctuations to short- and long-run relationships, while examining for possible asymmetries in the adjustment process. In a conventional Error Correction Model (ECM), all variables are used in first differences, except the error correction term (ECT) which is represented by the stationary residuals derived from the cointegrating vector (i.e. long-run relationship), indicating deviations from the long-run equilibrium and thus providing the speed of adjustment. This study used a PVECM, that is a system of equations that allows for decomposing short- and long-run asymmetric responses of producer (i.e. processor prices) to farm prices, as well as consumer (i.e. retail) prices to producer (i.e. processor) prices, in a more efficient way than an ECM. The PVECM used in the present investigation is an extension of the Greenwood-Nimmo and Shin (2013) study. In the present study, two main hypothesis are examined. The first hypothesis examines long-run asymmetry by testing if the upstream effects of price increases are larger than those of price decreases in the processor and retail segment. The second hypothesis investigates short-run asymmetry by testing if the 
positive short-run price effect is larger than its negative counterpart in the processor and retail segments.

Test results for all empirical models, presented in Table 3 (and Tables B1-B5 in Appendix B) and based on the Bayes' factors, support long- and short-run asymmetries, as well as the existence of stable long-run relationships for both processor and retail segments (i.e. farm-processor and processor-retail prices). In particular, Table 3 depicts the empirical findings at the EU-28 aggregate level, consisting of a panel of "food" index and its four subcomponents (cereals and bread; meat; milk, cheese and eggs; and oils and fat). This table presents results for two threshold PVECMs which capture the (asymmetric) transmission from farm to producer prices (Panel A), as well as from producer to consumer prices (Panel B). In both market segments presented in Panel A (processor) and B (retail), positive coefficients are larger in absolute value than their negative counterparts, indicating that the effects of upstream price increases are larger than those of price decreases (Bayes' Factor symmetry test statistics in the Table). We found that the speed of adjustment $(\rho)$ for the whole food supply chain and its components is rather sluggish. Regarding the processor (retail) segment, the speed of adjustment is about $12.3 \%(16.3 \%)$ for "food" and, for the four food components, ranged from $5.9 \%(14.4 \%)$ per month for "meat" ("milk, cheese and eggs") to $28.9 \%(25.5 \%)$ per month for "oils and fats" ("meat"). According to Greenwood-Nimmo and Shin (2013), sluggish adjustment is suggestive of weak competition and is also related to relatively extended periods of mispricing. Furthermore, we found evidence of positive long-run asymmetry in both segments (processor and retailer) for the "food" chain and its four components (Bayes' Factor symmetry test statistics in the Table). The long-run 
coefficients $\left(\alpha^{+}, \alpha^{-}\right)$of the "food" chain corresponding to the processor segment are around 1, while those corresponding to the retail segment are below 1 ( 0.881 and 0.814 , respectively), indicating that the long-run linkage between "food" retail and processor prices is much weaker that the long-run linkage between farm and processor prices. It is worth noting that all long-run coefficients corresponding to the four food subcomponents (cereals and bread; meat; milk, cheese and eggs; and oils and fat), in both segments (processor and retailer), are around 1, except for those for the "meat" component in the processor segment which are well below 1 ( 0.877 and 0.801 , respectively). This indicates that, in the long-run, meat processors are somewhat insulated from fluctuations in the meat (livestock) farm market, which might be among the factors causing the very sluggish speed of adjustment (5.9\%) reported for the producer segment for "meat". In addition, the empirical results indicate that, in all cases, the positive short-run price effect is larger than the negative counterpart, indicating the presence of positive short-run price asymmetries (Bayes' Factor symmetry test statistics in the Table). The magnitude of the additive (i.e. $\sum_{j=1}^{q-1} \pi_{j}^{+}, \sum_{j=1}^{q-1} \pi_{j}^{-}$) effect is larger in the processor segment than in the retail segment in the case of "cereals and bread", "milk, cheese and eggs" and "oils and fat", while the opposite holds for the rest of the cases. This means that, in the short-run and in the case of "cereals and bread", "milk, cheese and eggs" and "oils and fat", farm price changes are passed onto producer prices more forcefully than producer price changes onto retail prices. The opposite holds for the rest of the food chains ("food" and "meat"). Country specific empirical results are presented in Tables B1-B5 in Appendix B. The results show that for all cases the country-specific speed of adjustments in both segments (processor and retail) are sluggish, indicating weak competition and long periods of 
mispricing (Greenwood-Nimmo and Shin, 2013) at the country level. Furthermore, the results indicate the present of positive long- and short-run asymmetries across all individual counties and at both processor and retail levels (Bayes' Factor test results in Tables B1-B5 in Appendix B).

The empirical literature on food price pass-through is fairly extensive. The results of the various studies are not directly comparable due to differences in motivations and focus, data sources, sample periods and estimation methods. However, a number of general findings can be drawn from these data (Ferrucci et al., 2010) and these can be compared with the results of the present study.

- First, the food price pass-through varies largely depending on the product category. This finding is supported by London Economics (2004), which examined the passthrough of a large number of food categories across various EU countries. Several other studies confirmed the same finding for the United States, such Vavra and Goodwin (2005) comparing the pass-through in beef, chicken and eggs markets, Kinnucan and Forker (1987) for the dairy industry and Boyd and Brorsen (1988) for the pork industry. Base on the results presented in Table 3 and discussed above, the present study is consistent with previously published data in that variations were found in the short-run price pass-through across the four components of the food supply chain (cereals and bread; meat; milk, cheese and eggs; and oils and fat), as well as between these components and the aggregate level of the food supply chain. However, with regard to the long-run, the present study shows that there is a stong linkage between farmprocessor and processor-retail prices across the four food subcomponents, with the exception of the farm-processor price linkage of the "meat" component which is much 
weaker (Table 3). Furthermore, the aggregate food category shows a strong linkage between farm-processor prices, but a weaker relationship between processor-retail prices (Table 3).

- Second, the food price pass-through differs across countries. On average, the price pass-through in emerging economies is about three times bigger than in advanced economies (IMF, 2008). This could be partly attributed to the high share of food consumption and the significance of material (e.g. agricultural commodity) inputs in production in developing economies. However, composition effects alone cannot explain differences in the food price pass-through across countries. In particular, London Economics (2004) found significant variation in pass-through across EU countries, even across those with similar levels of economic development. Among factors explaining this finding could be structural factors, such as competitive conditions in the interior markets for the various food commodities and the openness to foreign trade. Based on the results presented in Tables B1-B5 in Appendix B, the present study demonstrates that price passthrough differs across countries and that composition effects alone cannot explain price pass-through differences across countries. In particular, the estimated country specific long-run coefficients for the aggregate "food" supply chain and its components (cereals and bread; meat; milk, cheese and eggs; and oils and fat) indicate that some countries show weak long-run farm-processor and processor-retailer price linkages, while some others show strong linkages. This finding does not depend on whether a country is an economically developed country, a developing country, a new or an old EU member state. Furthermore, along the same lines, the results show that county-specific short-run 
price pass-through estimates vary across countries for all food categories that were examined (Tables B1-B5, in Appendix B).

- Third, the pass-through to producer prices is expected to be higher than to consumer prices. Only a few studies have examined this issue, however, a general tendency is that the magnitude of pass-through decreases the further one moves along the food supply chain. This is because the share of total value added, attributed to agricultural commodity input costs, decreases as one moves down the food supply chain (i.e. from processed to final consumption goods). In the stage of final consumption goods, a relatively high share of total value added is accounted for by non-agricultural commodity input costs, such as transportation, energy, wages, rents, and packaging. The results presented in Table 3 (and Tables B1-B5 in Appendix B) and discussed above provide evidence that price passthrough from the farmer to processor is greater than from the processor to retailer.

- Finally, the food price pass-through is asymmetric. Many studies examining price transmission in agricultural and food markets indicate that processor and retail prices tend to respond more to input cost increases than decreases. This finding appears to hold across a variety of food products, counties and time periods. For example, Peltzmann (2000), investigating asymmetric price transmission for 282 products, including 120 agricultural and food commodities, found that asymmetric price transmission is widespread in the majority of producer and consumer markets. Furthermore, review studies by Meyer and von Cramon-Taubadel (2004) and Vavra and Goodwin (2005) provide support for asymmetric price transmission in the food price chain. The results presented in Table 3 (and Tables B1-B5 in Appendix B) and discussed above show sluggish adjustment towards the long-run equilibrium, indicating weak competition and 
long periods of mispricing in both processor and retail levels at the aggregate EU-28 level and at the EU country-specific level for the whole food supply chain and its four subcomponents. Furthermore, the results demonstrate positive long- and short-run asymmetries for all cases under study.

Imperfect competition in the food processing and retailing sectors might be a source of the asymmetric price transmission found in the present study, because it allows processors and/or retailers to make use of market power to transmit input price increases to a greater magnitude than input price reductions, often leading to positive price asymmetry. ${ }^{5}$ This may imply an increase in the price margin and/or price ratio of producer-farmer and retailer-producer. However, some studies have shown that asymmetric price transmission could occur even in competitive markets (Azzam, 1999). Furthermore, McCorriston et al.(2001) supported the idea that market power could be offset by increasing returns to scale and that the degree of price transmission could be higher in non-competitive markets than in competitive ones. Adjustment and menu costs could be another cause of asymmetric price transmission by preventing retail prices from adjusting because of the costs associated with making changes to retail prices (e.g. labelling and advertising), consumer disruption (e.g. due to consumers' sensitivity to price changes) and uncertainty about price changes being permanent or transitory. In particular, Azzam (1999) showed that, when retailers incur reprising costs, retail prices could be unchanged over a range of farm price changes. The search costs associated with

\footnotetext{
${ }^{5}$ Imperfect competition in the food processing and retailing sector has been demonstrated in several studies (Kaiser and Suzuki, 2006); furthermore, as indicated in the introduction, the C5 concentration ratio of the agricultural sector at the EU level is much smaller than that of the processing and retailing sectors, allowing them to exercise some degree of market power over farmers.
} 
local markets (Benson and Faminow, 1985) could be another source of asymmetric price transmission by preventing consumers from searching for products with lower prices, providing a degree of market power to local firms and thus passing on input price increases more quickly and rapidly than price decreases. Finally, public intervention (Gardner, 1975; Kinnucan and Forker, 1987) could cause asymmetry in food markets, because retailers might perceive increases in farm prices as permanent while seeing decreases as temporary and thus transmit increases in farm prices faster and more completely to consumer prices than decreases. Based on Meyer and von CramonTaubadel (2004), while all sources of asymmetry discussed above (market power, adjustment and menu costs, inventory management strategies and public intervention) can generate short-run asymmetries, only non-competitive behavior (i.e. market power) would seem to be capable of producing long-lasting asymmetric price adjustments.

\section{Concluding remarks}

The present study investigates asymmetric price transmission in the food supply chain and its components (cereals and bread; meat; milk, cheese and eggs; and oils and fat) at the EU-28 level and at EU country-specific level using a multivariate panel vector error correction model (PVECM). Furthermore, the present paper allows the examination of several issues frequently reported in studies on price transmission, such as whether the food price pass-through varies greatly across product category and across counties, and also whether the pass-through to producer prices is greater than to consumer prices. In the empirical investigation, six different datasets were used which were obtained from the "Food Prices Monitoring Tool", while the analysis in the disaggregate and country- 
specific level was constrained by data availability. The first dataset consists of monthly price series of the "food" price index and its four subindices (cereals and bread; meat; milk, cheese and eggs; and oils and fat) in the three segments of the supply chain (farm, processor and retail). The other five datasets consist of EU country-specific panels of monthly price indices of food and its four above-mentioned subcomponents in the three stages of the food supply chain. Applying the multivariate panel vector error correction model (PVECM), developed in the present study, we found strong evidence of positive long- and short-run asymmetric price transmission along the food supply chain and its four components at the EU-28 level, as well as at EU country-specific level for the processor and retailer segments. This indicates that a farm (producer) price increase is passed on more forcefully to the producer (consumer) price than a similar price decrease. The asymmetric price pass-through findings indicate rent-seeking behavior by processors (retailers) against farmers (processors). Furthermore, the positive long-run price transmission asymmetry findings of the present study can be attributed to the strong market power of the European food retailers over processors and, in turn, the strong market power of processors over farmers. The short-run asymmetric price transmission, in addition to market power, can be caused by factors such as adjustment and menu costs, search costs, inventory management strategies and policy intervention, among others. The results of the present study support the general findings of the existing literature, namely that the food price pass-through varies greatly across product category and across counties, and also that the pass-through to producer prices is greater than to consumer prices. 
The empirical findings of positive asymmetries indicate that final consumers are more likely to experience a decrease in their surpluses from a price increase at the farm level than an increase in their surpluses from a farm price decrease. However, the estimation of possible welfare losses that may exist due to asymmetric price transmission along the food supply chains examined in the present study requires additional research in terms of further analysis of the price variation of food products under examination, estimating margins, consumer surplus and total welfare. The possible presence of high consumer welfare losses may require intervention by antitrust authorities. Recent studies have supported the argument that retailers are continually gaining market power over farmers along the food supply chain and enjoy a certain advantage over farmers because of an increase in the margins between consumer prices and farm prices (EC, 2009; Saitone and Sexton, 2012). Possible abuse of market power by retailers may have caused a widening of gross margins (i.e. the gap between the retailer and the farmer price) for a wide variety of food products. However, additional factors might have contributed to the widening of gross margins, such as the increase of agricultural and food imports, which have benefited food retailers, and the higher productivity growth in the farm sector compared to that of the retail sector, among others.

Finally, future research could develop in various directions. For example, investigation of horizontal price transmission between countries and possibly between sectors, as well as extending the present study to examine the effect of price spikes, such as those occuring around 2008 and $2013 .^{6}$

\footnotetext{
${ }^{6}$ In the present study, price spikes are taken into consideration by the autoregressive components of the model. Furthermore, we could break the time period into three sub-periods (the first before 2008, the second between 2008 and 2013, and the third after 2013) to examine the possibility of structural breaks due to the 2008 and 2013 price spikes. However, we avoided this approach for
} 
two main reasons: First, the time period under examination is too short (2005-2016) to allow us to break it down into sub-periods and, second, the amount of empirical estimates and information obtained at both the sector and country levels would be extensive and too difficult to handle within the scope of the present study. 


\section{Bibliography}

Abdulai, A., (2002). "Using threshold cointegration to estimate asymmetric price transmission in the Swiss pork market". Applied Economics, 34 (6), 679-687.

Azzam, A.M. (1999). "Asymmetry in rigidity in farm-retail price transmission". American Journal of Agricultural Economics, 81, 525-533.

Ben-Kaabia, M., Gil, J.M., 2007. "Asymmetric price transmission in the Spanish lamb sector”. European Review of Agricultural Economics, 34 (1), 53-80.

Benson, B.L., Faminow, M.D. (1985). "An alternative view of pricing in retail food markets". American Journal of Agricultural Economics, 67, 296-305.

Boyd, M.S., and B.W. Brorsen (1988). "Price asymmetry in the U.S. pork marketing channel”, North Central Journal of Agricultural Economics, 10, 103-110.

Bukeviciute, Lina, Adriaan Dierx and Fabienne Ilzkovitz, 'The functioning of the food supply chain and its effect on food prices in the European Union'. European Commission, Directorate General for Economic and Financial Affairs, European Economy, Occasional Papers No.47, 2009, 37 pp.(http://ec.europa.eu/economy_finance/publications)

Capps, O., Sherwell, P. (2007). "Alternative approaches in detecting asymmetry in farmretail price transmission of fluid milk". Agribusiness, 23(3), 313-331.

European Commission (EC), "Analysis of price transmission along the food supply chain in the EU", Commission Staff Working Document, SEC (2009) 1450, http://ec.europa.eu/economy_finance/publications/publication16067_en.pdf.

Chib, S. (1995). "Marginal Likelihood from the Gibbs Output". Journal of the American Statistical Association, 90(432), 1313-1321.

European Commission (EC), "Study on the economic impact of modern retail on choice and innovation in the EU food sector", Final report, 2014, $450 \mathrm{pp}$. (http://ec.europa.eu/competition/publications/KD0214955ENN.pdf).

EU Agricultural Markets Briefs (EUAMB), "You are part of the food chain: key facts and figures on the food supply chain in the European Union", European Commission, No 4, June 2015. (http://ec.europa.eu/agriculture/markets-anures d-prices/market-briefs/index_en.htm)

Fearnhead, P. (2007). "Computational methods for complex stochastic systems: a review of some alternatives to MCMC", Statistics and Computing, 18(2):151-171. 
Ferrucci, G., Jimenez, R and Onorante, L (2010). "Food price pass-through in the Euro Area. The role of Asymmetries and non-linearities". European Central Bank Working Paper Series, No 1168.

Fousekis, P., Grigoriadis, V. (2017). "Join price dynamics of quality differentiated commodities: copula evidence from coffee varieties". European Review of Agricultural Economics, 44(2), 337-358.

Fousekis, P., Katrakilidis, C. and Trachanas, E. (2016)."Vertical price transmission in the US beef sector: Evidence from the nonlinear ARDL model". Economic Modeling, 52, 499-506

Frey, G., Manera, M., (2007). "Econometric models of asymmetric price transmission". Journal of Economic Surveys, 21 (2), 349-415.

Gardner, B.L. (1975). "The farm-retail price spread in a competitive food industry", American Journal of Agricultural Economics, 57, 383-406.

Gervais, J.P. (2011). "Disentangling nonlinearities in the long- and the short-run price relationships: an application to the US hog-pork supply chain". Applied Economics, 43 (12), 1497-1510.

Girolami, M., Calderhead, B. (2011)."Riemann manifold Langevin and Hamiltonian Monte Carlo methods". Journal of the Royal Statistical Society: Series B, 73(2),123-214.

Greenwood-Nimmo, M., Shin, Y. (2013). "Taxation and the asymmetric adjustment of selected retail energy prices in the UK". Economics Letters, 121 (3), 411-416.

Goodwin, B.K., Harper, D.C. (2000). "Price transmission, threshold behaviour and asymmetric adjustment in the U.S. pork sector". Journal of Agricultural \& Applied Economics, 32, 543-553.

Goodwin, B.K., Holt, M.T. (1999). "Asymmetric Adjustment and Price Transmission in the U.S. Beef Sector”. American Journal of Agricultural Economics, 79, 630-637.

Goodwin, B.K., Piggott, N.E. (2001). "Spatial Market Integration in the Presence of Threshold Effects". American Journal of Agricultural Economics, 83(2), 302-317.

Houck, P.J. (1977). "An approach to specifying and estimating nonreversible functions", American Journal of Agricultural Economics, 59, 570-72.

International Monetary Fund (2008), “Is inflation back? Commodity prices and inflation", World Economic Outlook, Chapter III, October, pp. 93-128.

Kaiser, H., Suzuki, N. 2006. New Empirical Industrial Organization \& the Food System. New York, U.S.: Peter Lang Publishing Inc. 357 p. 
Kinnucan, H.W., Forker, O.D. (1987). “Asymmetry in farm-retail price transmission for major dairy products". American Journal of Agricultural Economics, 69(2), 285-292.

Lass, D.A. (2005). "Asymmetric response of retail milk prices in the northeast revised”.Agribusiness, 21, 493-508.

London Economics (2004), Investigation of the determinants of farm-retail prices spreads, Final report to DEFRA, U.K.

McCorriston, S., Morgan, C.W. and Rayner, A.J. (2001). "Price transmission: the interaction between market power and returns to scale". European Review of Agricultural Economics, 28, 143-159.

Meyer, J., von Cramon-Taubadel, S. (2004). “Asymmetric price transmission: a survey". Journal of Agricultural Economics, 55(3), 581-611.

Peltzman, S. (2000). "Prices rise faster than they fall". Journal of Political Economy, 108(3), 466-502.

Polemis, M.L., Tsionas, M.G. (2016). "An alternative semiparametric approach to the modeling of asymmetric gasoline price adjustment". Energy Economics, 56, 384-388.

Panagiotou, D., Stavrakoudis, A. (2015). "Price asymmetry between different postk cuts in the USA: a copula approach". Agricultural and Food Economics, 3:6, https://doi.org/10.1186/s40100-015-0029-2

Rezitis, A.N., Reziti, I. (2011). "Threshold Cointegration in the Greek Milk Market".Journal of International Food and Agribusiness Marketing, 23(3), 231-246.

Saitone, T., Sexton, R. (2012). "Market structure and competition in the US food industries. Implications for the 2012 Farm Bill”, (Available at:) http://www.aei.org/files/2012/04/02/-market-structure-and-competition-in-the-us-foodindustries_102234192168.pdf.

Serra, T., Goodwin, B.K. (2003). "Price transmission and asymmetric adjustment in the Spanish dairy sector". Applied Economics, 35, 1889-1899.

Shin, Y., Yu, B., Greenwood-Nimmo, M.J., 2013. Modelling asymmetric cointegration anddynamic multipliers in a nonlinear ARDL framework. Horrace.

Tiffin, R., Dawson, P., 2000. "Structural breaks, cointegration, and the farm-retail price spread for lamb”. Applied Economics, 32 (10), 1281-1286.

Varva, P., Goodwin, P., 2005. Analysis of price transmission along the food chain.Working Paper No 3. OECD Food, Agriculture, and Fisheries. 
vonCramon-Taubadel, S., Fahlbusch, S. (1994). Identifying asymmetric price transmission with error correction models. Poster Session EAAE European Seminar in Reading.

vonCramon-Taubadel, S., Loy, J.P. (1999). "The identification of asymmetric price transmission process with integrated time series".Jahrbucher for Nationalokonomic und Statistik, 218, 85-106.

Ward, R.W. (1982). "Asymmetry in retail, wholesale and shipping point pricing for fresh vegetables”. American Journal of Agricultural Economics, 64 (2), 205-212.

Wolffram, R. (1971). "Positive measures of aggregate supply elasticities: some new approaches-some critical notes". American Journal of Agricultural Economics, 53, 3569.

Zhang, P., Fletcher, S.M., Carley, D.H., (1995). "Peanut price transmission asymmetry in peanut butter". Agribusiness, 11 (1), 13-20. 
Table 1: Descriptive Statistics: Monthly price indices of the period 2005:01-2016:09 (2010=100)

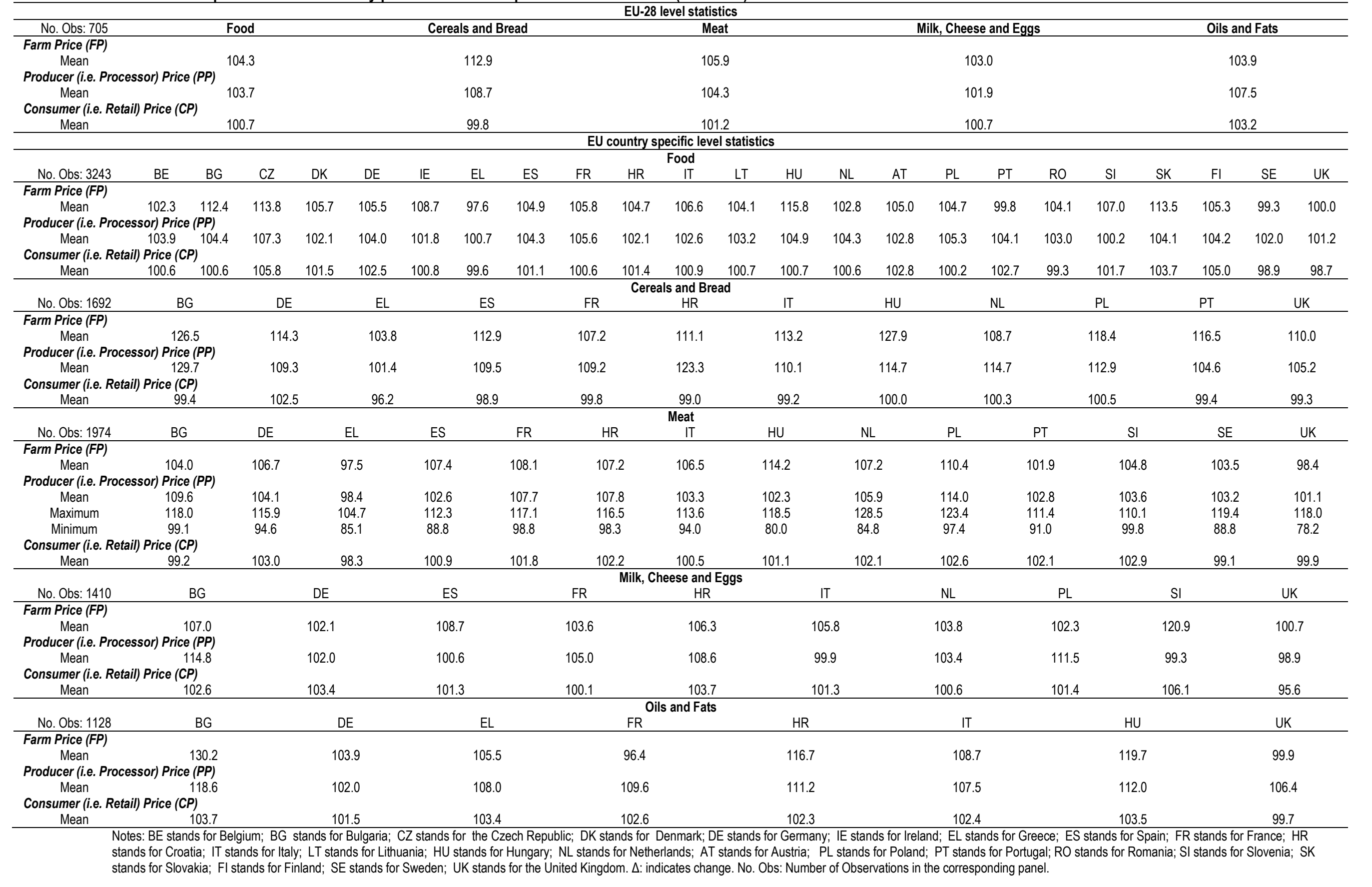


Table 2. Bayes factors for model selection

\begin{tabular}{c|ccccc}
\hline & $\mathrm{p}=2$ & $\mathrm{p}=3$ & $\mathrm{p}=4$ & $\mathrm{p}=5$ & $\mathrm{p}=\mathbf{8}$ \\
\hline $\mathrm{q}=1$ & 1.000 & 7.32 & 9.44 & 11.15 & 13.76 \\
$\mathrm{q}=2$ & 21.13 & 14.18 & 17.44 & 12.10 & 15.44 \\
$\mathrm{q}=3$ & 33.54 & 37.12 & 41.55 & 46.12 & 35.17 \\
$\mathrm{q}=4$ & 14.12 & 11.33 & 155.23 & 55.76 & 32.10 \\
$\mathrm{q}=8$ & 11.14 & 5.12 & 1.10 & 0.81 & 0.032 \\
\hline
\end{tabular}


Table 3: Aggregate EU-28 model (2005:01-1016:09)

\begin{tabular}{|c|c|c|c|c|c|c|}
\hline \multirow{2}{*}{\multicolumn{7}{|c|}{ Farm to Producer Panel A }} \\
\hline & & & & & & \\
\hline \multicolumn{7}{|l|}{ Estimated Coefficients } \\
\hline$\rho$ & $\begin{array}{l}-0.123 \\
(0.003)\end{array}$ & $\begin{array}{l}-0.271 \\
(0.015)\end{array}$ & $\begin{array}{l}-0.059 \\
(0.005)\end{array}$ & & $\begin{array}{l}-0.244 \\
(0.007)\end{array}$ & $\begin{array}{l}-0.289 \\
(0.008)\end{array}$ \\
\hline$\alpha^{+}$ & $\begin{array}{l}1.035 \\
(0.011)\end{array}$ & $\begin{array}{l}1.042 \\
(0.020)\end{array}$ & $\begin{array}{l}0.877 \\
(0.012)\end{array}$ & & $\begin{array}{l}1.122 \\
(0.011)\end{array}$ & $\begin{array}{l}1.103 \\
(0.021)\end{array}$ \\
\hline$\alpha^{-}$ & $\begin{array}{l}0.982 \\
(0.005)\end{array}$ & $\begin{array}{l}0.977 \\
(0.004)\end{array}$ & $\begin{array}{l}0.801 \\
(0.004)\end{array}$ & & $\begin{array}{l}1.074 \\
(0.006)\end{array}$ & $\begin{array}{l}0.971 \\
(0.011)\end{array}$ \\
\hline$\pi_{0}^{+}$ & $\begin{array}{l}0.530 \\
(0.007)\end{array}$ & $\begin{array}{l}0.255 \\
(0.012)\end{array}$ & $\begin{array}{l}0.517 \\
(0.012)\end{array}$ & & $\begin{array}{l}0.234 \\
(0.005)\end{array}$ & $\begin{array}{l}0.488 \\
(0.006)\end{array}$ \\
\hline$\pi_{0}^{-}$ & $\begin{array}{l}0.482 \\
(0.005)\end{array}$ & $\begin{array}{l}0.230 \\
(0.005)\end{array}$ & $\begin{array}{l}0.472 \\
(0.003)\end{array}$ & & $\begin{array}{l}0.203 \\
(0.003)\end{array}$ & $\begin{array}{l}0.422 \\
(0.005)\end{array}$ \\
\hline$\sum_{j=1}^{q-1} \pi_{j}^{+}$ & $\begin{array}{l}0.521 \\
(0.011)\end{array}$ & $\begin{array}{l}0.702 \\
(0.012)\end{array}$ & $\begin{array}{l}0.748 \\
(0.021)\end{array}$ & & $\begin{array}{l}0.541 \\
(0.012)\end{array}$ & $\begin{array}{l}0.616 \\
(0.018)\end{array}$ \\
\hline$\sum_{j=1}^{q-1} \pi_{j}^{-}$ & $\begin{array}{l}0.497 \\
(0.004)\end{array}$ & $\begin{array}{l}0.681 \\
(0.003)\end{array}$ & $\begin{array}{l}0.725 \\
(0.003)\end{array}$ & & $\begin{array}{l}0.530 \\
(0.004)\end{array}$ & $\begin{array}{l}0.597 \\
(0.008)\end{array}$ \\
\hline$\lambda$ & & & & $\begin{array}{l}0.0049 \\
(0.0004)\end{array}$ & & \\
\hline \multicolumn{7}{|c|}{ Symmetry tests, using Bayes' Factor } \\
\hline$H_{0}: \alpha^{+}=\alpha^{-}$ & 25.31 & 22.44 & 25.81 & & 32.44 & 27.81 \\
\hline$H_{0}: \pi_{0}^{+}=\pi_{0}^{-}$ & 59.15 & 61.13 & 65.44 & & 44.12 & 51.20 \\
\hline$H_{0}: \sum_{j=1}^{q-1} \pi_{j}^{+}=\sum_{j=1}^{q-1} \pi_{j}^{-}$ & 61.14 & 58.43 & 77.81 & & 66.30 & 77.30 \\
\hline \multicolumn{7}{|c|}{ Long-run relationship, using Bayes' Factor } \\
\hline$\rho=0$ & 72.44 & 63.12 & 82.15 & & 97.57 & 92.40 \\
\hline$\rho=\delta^{+}=\delta^{-}$ & 81.32 & 77.44 & 101.34 & & 92.77 & 91.55 \\
\hline \multicolumn{7}{|c|}{ Producer to Consumer Panel B } \\
\hline \multicolumn{7}{|l|}{ Estimated Coefficients } \\
\hline$\rho$ & $\begin{array}{l}-0.163 \\
(0.007)\end{array}$ & $\begin{array}{l}-0.177 \\
(0.004)\end{array}$ & $\begin{array}{l}-0.255 \\
(0.008)\end{array}$ & & $\begin{array}{l}-0.144 \\
(0.005)\end{array}$ & $\begin{array}{l}-0.231 \\
(0.007)\end{array}$ \\
\hline$\alpha^{+}$ & $\begin{array}{l}0.881 \\
(0.017)\end{array}$ & $\begin{array}{l}1.121 \\
(0.012)\end{array}$ & $\begin{array}{l}1.144 \\
(0.011)\end{array}$ & & $\begin{array}{l}1.044 \\
(0.017)\end{array}$ & $\begin{array}{l}1.115 \\
(0.021)\end{array}$ \\
\hline$\alpha^{-}$ & $\begin{array}{l}0.814 \\
(0.005)\end{array}$ & $\begin{array}{l}1.0032 \\
(0.004)\end{array}$ & $\begin{array}{l}1.081 \\
(0.003)\end{array}$ & & $\begin{array}{l}0.972 \\
(0.002)\end{array}$ & $\begin{array}{l}1.011 \\
(0.003)\end{array}$ \\
\hline$\pi_{0}^{+}$ & $\begin{array}{l}0.355 \\
(0.007)\end{array}$ & $\begin{array}{l}0.255 \\
(0.009)\end{array}$ & $\begin{array}{l}0.432 \\
(0.007)\end{array}$ & & $\begin{array}{l}0.165 \\
(0.011)\end{array}$ & $\begin{array}{l}0.167 \\
(0.013)\end{array}$ \\
\hline$\pi_{0}^{-}$ & $\begin{array}{l}0.311 \\
(0.002)\end{array}$ & $\begin{array}{l}0.202 \\
(0.001)\end{array}$ & $\begin{array}{l}0.388 \\
(0.002)\end{array}$ & & $\begin{array}{l}0.143 \\
(0.005)\end{array}$ & $\begin{array}{l}0.112 \\
(0.003)\end{array}$ \\
\hline$\sum_{j=1}^{q-1} \pi_{j}^{+}$ & $\begin{array}{l}0.581 \\
(0.012)\end{array}$ & $\begin{array}{l}0.389 \\
(0.033)\end{array}$ & $\begin{array}{l}0.821 \\
(0.025)\end{array}$ & & $\begin{array}{l}0.438 \\
(0.012)\end{array}$ & $\begin{array}{l}0.355 \\
(0.012)\end{array}$ \\
\hline$\sum_{j=1}^{q-1} \pi_{j}^{-}$ & $\begin{array}{l}0.512 \\
(0.007)\end{array}$ & $\begin{array}{l}0.332 \\
(0.008)\end{array}$ & $\begin{array}{l}0.788 \\
(0.005)\end{array}$ & & $\begin{array}{l}0.404 \\
(0.004)\end{array}$ & $\begin{array}{l}0.297 \\
(0.002)\end{array}$ \\
\hline \multicolumn{3}{|l|}{$\lambda^{j=1}$} & & $\begin{array}{l}0.0079 \\
(0.0002)\end{array}$ & & \\
\hline \multicolumn{7}{|c|}{ Symmetry tests, using Bayes' Factor } \\
\hline$H_{0}: \alpha^{+}=\alpha^{-}$ & 21.12 & 17.21 & 21.37 & & 12.1 & 45.32 \\
\hline$H_{0}: \pi_{0}^{+}=\pi_{0}^{-}$ & 32.55 & 34.55 & 48.12 & & 17.44 & 23.16 \\
\hline$H_{0}: \sum_{j=1}^{q-1} \pi_{j}^{+}=\sum_{j=1}^{q-1} \pi_{j}^{-}$ & 44.70 & 65.12 & 51.25 & & 32.55 & 32.10 \\
\hline \multicolumn{7}{|c|}{ Long-run relationship, using Bayes' Factor } \\
\hline$\rho=0$ & 77.17 & 54.12 & 77.14 & & 98.12 & 102.3 \\
\hline$\rho=\delta^{+}=\delta^{-}$ & 55.81 & 78.98 & 65.25 & & 79.34 & 98.35 \\
\hline
\end{tabular}

Notes: Estimated coefficients report posterior means and posterior standard deviations of the most important parameters of the model. 


\section{Figure 1}

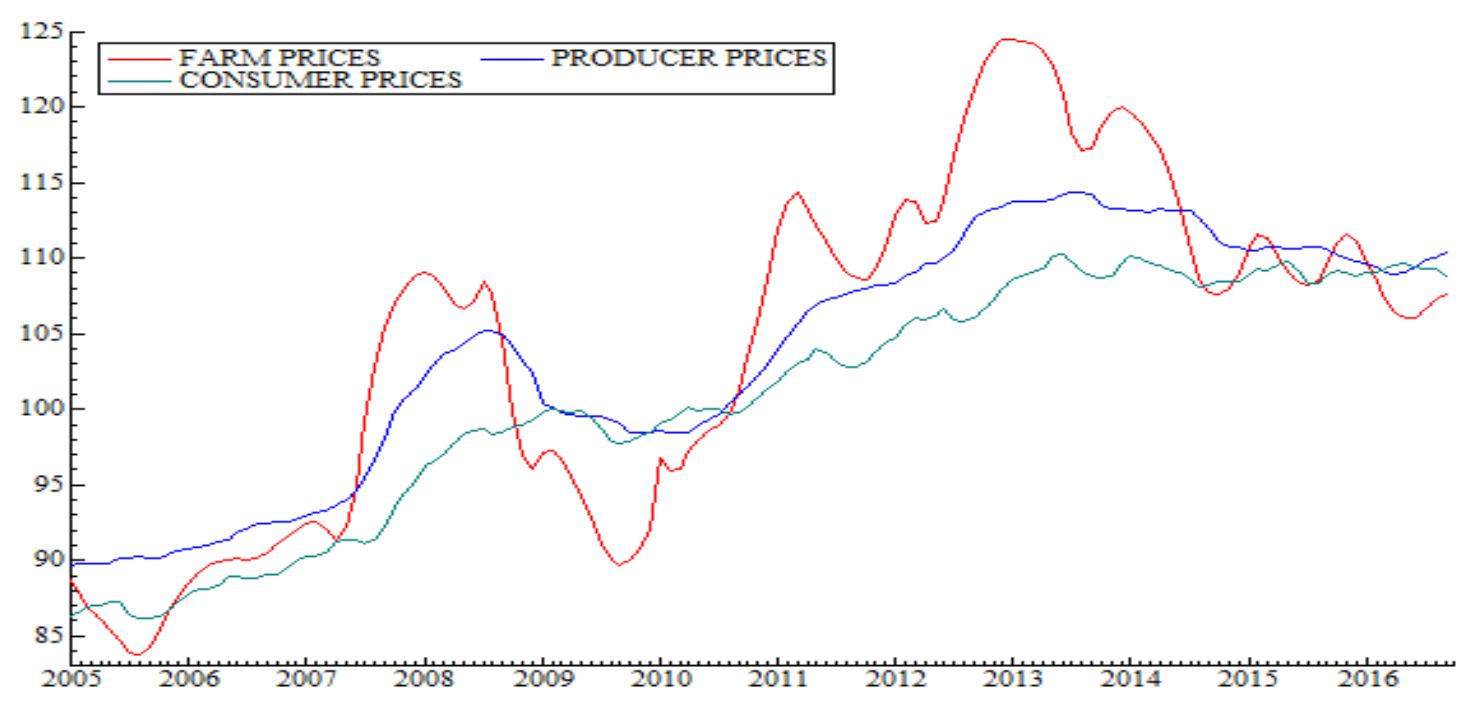

Notes: Food price indexes $(2010=100)$ of farm prices, producer prices and consumer prices (EU-28; period 2005:1-2016:09).

\section{Figure 2}

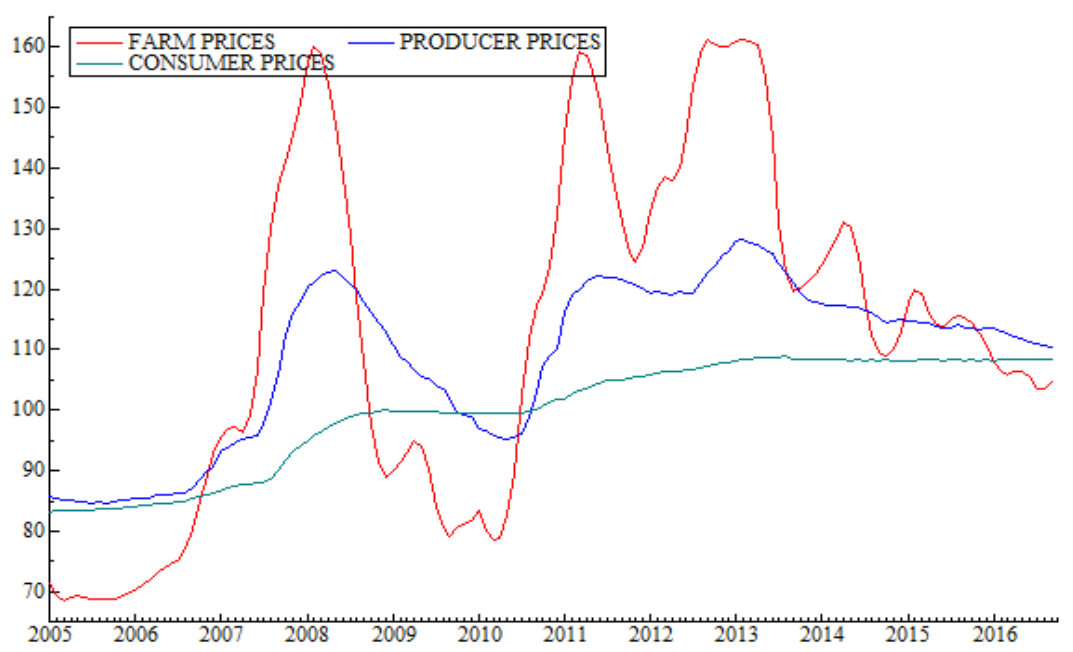

Notes: Bread and cereals price indexes $(2010=100)$ of farm prices, producer prices and consumer prices (EU-28; period 2005:1-2016:09).

\section{Figure 3}

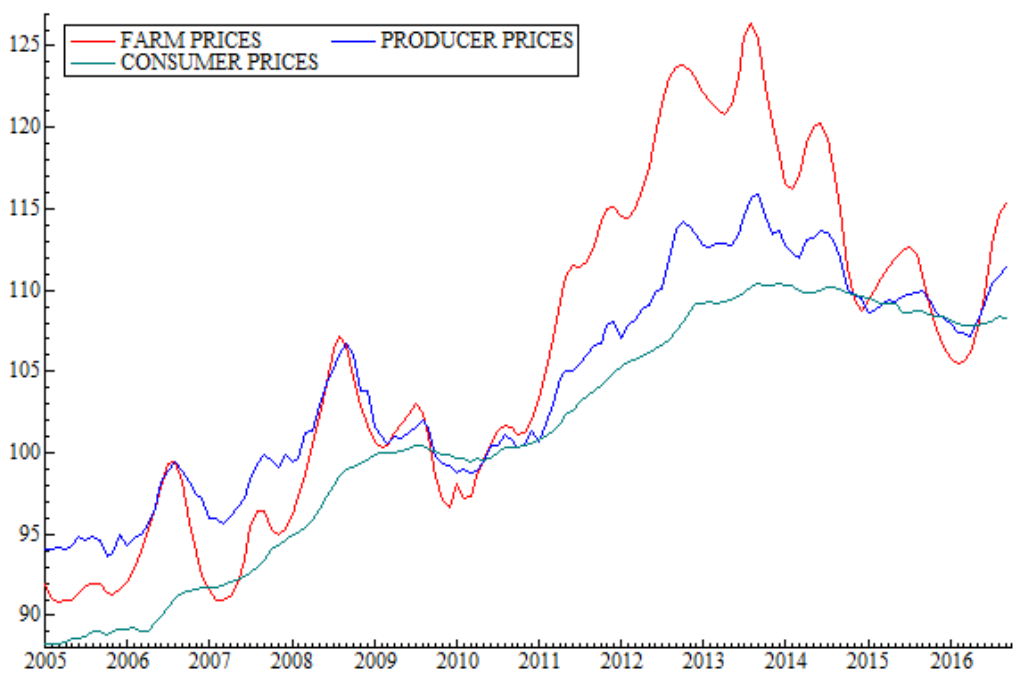

Notes: Meat price indexes $(2010=100)$ of farm prices, producer prices and consumer prices (EU-28; period 2005:1-2016:09). 
Figure 4

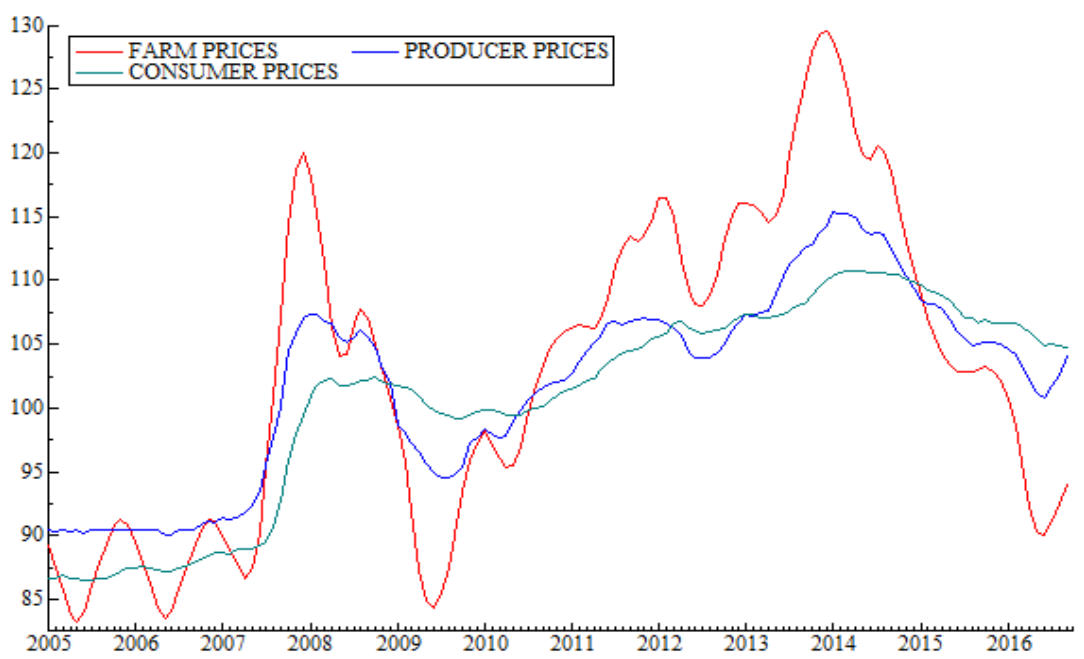

Notes: Milk, cheese and eggs price indexes $(2010=100)$ of farm prices, producer producer prices and consumer prices (EU-28; period 2005:1-2016:09).
Figure 5

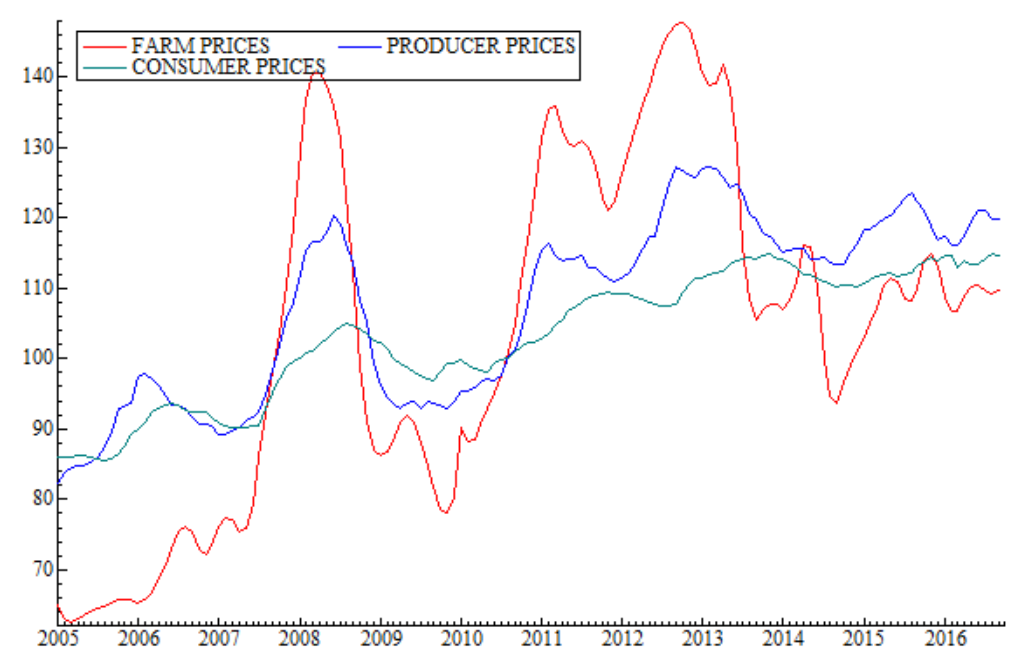

Notes: Oils and fats price indexes $(2010=100)$ of farm prices, producer prices and consumer prices (EU-28; period 2005:1-2016:09). 


\section{A. Technical Appendix: Numerical Techniques A1. Computational strategy}

We have a (large) Bayesian PVECM whose dimension is equal to $\mathrm{n}$, the number of EU Member States. Without the random-coefficient specification, estimation of this VAR would present considerable challenges. MCMC analysis can be easily implemented using standard techniques involving the Gibbs sampler. We first proceed on the assumption that $\lambda$ is known so that we can construct the relevant matrices of regressors. Parameter $\lambda$ is drawn afterwards using the so-called griddy Gibbs approach from its conditional posterior distribution. Let us write the PVECM in the following form:

$$
\mathbf{w}_{\mathrm{t}}=\sum_{\mathrm{j}=1}^{\mathrm{p}-1} \Gamma_{\mathrm{j}} \mathbf{w}_{\mathrm{t}-\mathrm{j}}+\mathbf{Z}_{\mathrm{t}} \xi+\boldsymbol{\varepsilon}_{\mathrm{t}} \triangleq \mathbf{X}_{\mathrm{t}} \boldsymbol{\beta}+\boldsymbol{\varepsilon}_{\mathrm{t}}
$$

The VAR can be written as

$$
\mathbf{w}_{\mathrm{i}}=\mathrm{X} \boldsymbol{\beta}_{\mathrm{i}}+\boldsymbol{\varepsilon}_{\mathrm{i}}, \mathrm{i}=1, \ldots, \mathrm{n}
$$

Making the substitution $\boldsymbol{\beta}_{\mathrm{i}}=\overline{\boldsymbol{\beta}}+\eta_{\mathrm{i}}, \boldsymbol{\eta}_{\mathrm{i}} \sim \mathcal{N}_{\mathrm{K}}(\mathbf{0}, \mathbf{\Omega})$ we obtain:

$$
\mathbf{w}_{\mathrm{i}}=\mathrm{X}_{\mathrm{i}} \overline{\boldsymbol{\beta}}+\mathbf{e}_{\mathrm{i}}
$$

where $\mathbb{E}\left(\mathbf{e}_{\mathrm{i}}\right)=\mathbf{0}_{\mathrm{T}}$ and $\mathbb{E}\left(\mathbf{e}_{\mathrm{i}} \mathbf{e}_{\mathrm{j}}^{\prime}\right)=\delta_{\mathrm{ij}} \mathbf{X}_{\mathrm{i}} \boldsymbol{\Omega} \mathbf{X}_{\mathrm{j}}^{\prime}+\sigma_{\mathrm{ij}} \mathbf{I}_{\mathrm{T}}$, where $\delta_{i j}$ is Kronecker's delta.

Suppose $\mathbf{w}=\left[\begin{array}{c}\mathbf{w}_{1} \\ \vdots \\ \mathbf{w}_{n}\end{array}\right], \quad \mathbf{X}=\left(\begin{array}{ccc}\mathbf{X}_{1} & \cdots & \mathbf{0} \\ \vdots & \ddots & \vdots \\ \mathbf{0} & \cdots & \mathbf{X}_{n}\end{array}\right)$ and $\mathbf{e}=\left[\begin{array}{l}\mathbf{e}_{1} \\ \vdots \\ \mathbf{e}_{n}\end{array}\right]$ so that the PVECM can be represented as: 


$$
\mathbf{w}=X \bar{\beta}+e
$$

and $\mathrm{E}\left(\mathrm{ee}^{\prime}\right)=\mathrm{X}\left(\Omega \otimes \mathrm{I}_{\mathrm{n}}\right) \mathrm{X}^{\prime}+\sum \otimes \mathrm{I}_{\mathrm{T}} \triangleq \mathrm{V}$.The likelihood function is

$$
\mathcal{L}(\boldsymbol{\theta} ; \mathbf{w}, \mathbf{X}) \propto|\mathbf{V}|^{-1 / 2} \exp \left\{-\frac{1}{2}(\mathbf{w}-\mathbf{X} \overline{\boldsymbol{\beta}})^{\prime} \mathbf{V}^{-1}(\mathbf{w}-\mathbf{X} \overline{\boldsymbol{\beta}})\right\}
$$

and the posterior can be obtained from Bayes' theorem:

$$
\mathrm{p}(\boldsymbol{\theta} \mid \mathbb{Y}) \propto \mathcal{L}(\boldsymbol{\theta} ; \mathbf{w}, \mathbf{X}) \mathrm{p}(\boldsymbol{\theta})
$$

where $\mathbb{Y}=[\mathbf{w}, \mathbf{X}]$ denotes the data.

As we can see, the posterior is a complicated function of the threshold parameter, $\lambda$.

The parameters $\theta$ consists of $\bar{\beta}, \lambda, \Sigma, \Omega$.

The dimensionality of the parameter vector, despite the fact that we have a Bayesian

VAR is small as there are $K$ elements in $\bar{\beta}, \frac{K(K+1)}{2}$ different elements in $\boldsymbol{\Omega}$ and we have a single-factor model for the cross-sectional covariance matrix $\boldsymbol{\Sigma}$.

Marginal likelihoods are computed using the "candidate's formula" (Chib, 1995):

$$
\mathfrak{M}_{\mathrm{g}}=\frac{\mathcal{L}(\hat{\boldsymbol{\theta}} ; \mathbb{Y}) \mathrm{p}(\hat{\boldsymbol{\theta}})}{(2 \pi)^{-\mathrm{d}_{\theta} / 2}|\mathrm{C}|^{-1 / 2}}, \forall \mathrm{g} \in \mathcal{G}
$$

where $\hat{\boldsymbol{\theta}}=\mathrm{S}^{-1} \sum_{s=1}^{\mathrm{s}} \boldsymbol{\theta}^{(\mathrm{s})}, \mathrm{C}=\mathrm{S}^{-1} \sum_{\mathrm{s}=1}^{\mathrm{s}}\left(\boldsymbol{\theta}^{(\mathrm{s})}-\hat{\boldsymbol{\theta}}\right)\left(\boldsymbol{\theta}^{(\mathrm{s})}-\hat{\boldsymbol{\theta}}\right)^{\prime}$, and $\left\{\boldsymbol{\theta}^{(\mathrm{s})}, \mathrm{s}=1, \ldots, \mathrm{S}\right\}$ represents the MCMC draws for the parameters. The denominator is based on a normal approximation to the posterior $\mathrm{p}(\boldsymbol{\theta} \mid \mathbb{Y})$ at the point $\boldsymbol{\theta}=\hat{\boldsymbol{\theta}}$. 
We deviate from standard practice that uses the Gibbs sampler in the context of Bayesian VAR models. Part of the problem, is that the priors on the different element of $\boldsymbol{\Sigma}$ and $\mathbf{\Omega}$ are non-standard. Our procedure is based on the Langevin Diffusion MCMC methods proposed by Girolami and Calderhead (2011). As matrix $\boldsymbol{\Sigma}$ is not available in closed form we do have to update the common factor $f_{t}$ via a separate MCMC step. The set of common factor values is jointly updated using, again, a Girolami and Calderhead (2011) MCMC update.

\section{A2. Markov Chain Monte Carlo}

Following Girolami and Calderhead (2011) we utilize Metropolis-adjusted Langevin and Hamiltonian Monte Carlo sampling methods defined on the Riemann manifold, since we are sampling from target densities with high dimensions that exhibit strong degrees of correlation. Consider the Langevin diffusion:

$$
d \boldsymbol{\theta}(t)=\frac{1}{2} \nabla \log p(\boldsymbol{\theta}(t) ; \mathbb{Y}) d t+d \mathbf{B}(t)
$$

where B denotes the D-dimensional Brownian motion. The first-order Euler discretization provides the following candidate generation mechanism:

$$
\boldsymbol{\theta}^{*}=\boldsymbol{\theta}^{o}+\frac{1}{2} \varepsilon^{2} \nabla \log p\left(\boldsymbol{\theta}^{o} ; \mathbb{Y}\right)+\varepsilon \mathbf{Z}
$$

where $\mathbf{z} \sim \mathcal{N}_{D}(\mathbf{0}, \mathbf{I})$, and $\varepsilon>0$ is the integration step size. Since the discretization induces an unavoidable error in approximation of the posterior, a Metropolis stepis used, where the proposal density is

$$
q\left(\boldsymbol{\theta}^{*} \mid \boldsymbol{\theta}^{o}\right)=\mathcal{N}_{D}\left(\boldsymbol{\theta}^{o}+\frac{1}{2} \varepsilon^{2} \nabla \log p\left(\boldsymbol{\theta}^{o} ; \mathbb{Y}\right), \varepsilon^{2} \mathbf{I}\right),
$$


with acceptance probability $a\left(\boldsymbol{\theta}^{o}, \boldsymbol{\theta}^{*}\right)=\min \left\{1, \frac{p\left(\boldsymbol{\theta}^{*} \mid \mathbb{Y}\right) q\left(\boldsymbol{\theta}^{o} \mid \boldsymbol{\theta}^{*}\right)}{p\left(\boldsymbol{\theta}^{o} \mid \mathbb{Y}\right) q\left(\boldsymbol{\theta}^{*} \mid \boldsymbol{\theta}^{o}\right)}\right\}$. Here $\mathbb{Y}$ denotes the available data. The Brownian motion of the Riemann manifold is given by:

$d \tilde{\mathbf{B}}_{i}(t)=|\mathbf{G}(\boldsymbol{\theta}(t))|^{-1 / 2} \sum_{j=1}^{d} \frac{\partial}{\partial \boldsymbol{\theta}_{j}}\left[\mathbf{G}^{-1}(\boldsymbol{\theta}(t))_{i j}|\mathbf{G}(\boldsymbol{\theta}(t))|^{1 / 2}\right] d t+\left[\sqrt{\mathbf{G}^{-1}(\boldsymbol{\theta}(t))} d \mathbf{B}(t)\right]_{i}$,

for $i=1, \ldots, D$.

The discrete form of the above stochastic differential equations is:

$$
\begin{gathered}
\boldsymbol{\theta}_{i}^{*}=\boldsymbol{\theta}_{i}^{o}+\frac{1}{2} \varepsilon^{2}\left[\mathbf{G}^{-1}\left(\boldsymbol{\theta}^{o}\right) \nabla \log p\left(\boldsymbol{\theta}^{o} ; \mathbf{Y}\right)\right]_{i}-\varepsilon^{2} \sum_{j=1}^{d}\left[\mathbf{G}^{-1}\left(\boldsymbol{\theta}^{o}\right) \frac{\partial \mathbf{G}\left(\boldsymbol{\theta}^{o}\right)}{\partial \boldsymbol{\theta}_{j}} \mathbf{G}^{-1}\left(\boldsymbol{\theta}^{o}\right)\right]_{i j}+ \\
\varepsilon^{2} \sum_{j=1}^{d} \mathbf{G}^{-1}\left(\boldsymbol{\theta}^{o}\right)_{i j} \operatorname{tr}\left[\mathbf{G}^{-1}\left(\boldsymbol{\theta}^{o}\right) \frac{\partial \mathbf{G}\left(\boldsymbol{\theta}^{o}\right)}{\partial \boldsymbol{\theta}_{j}}\right]+\varepsilon\left[\sqrt{\mathbf{G}^{-1}(\boldsymbol{\theta}(t)) \mathbf{z}}\right]_{i} \triangleq \boldsymbol{\mu}\left(\boldsymbol{\theta}^{o}, \varepsilon\right)_{i}+\varepsilon\left[\sqrt{\mathbf{G}^{-1}(\boldsymbol{\theta}(t)) \mathbf{z}}\right]_{i}
\end{gathered}
$$

The proposal density is $\boldsymbol{\theta}^{*} \mid \boldsymbol{\theta}^{o} \sim \mathcal{N}_{d}\left(\boldsymbol{\mu}\left(\boldsymbol{\theta}^{o}, \varepsilon\right), \varepsilon^{2} \mathbf{G}^{-1}\left(\boldsymbol{\theta}^{o}\right)\right)$ and the acceptance probability has the standard Metropolis form:

$$
a\left(\boldsymbol{\theta}^{o}, \boldsymbol{\theta}^{*}\right)=\min \left\{1, \frac{p\left(\boldsymbol{\theta}^{*} \mid \mathbb{Y}\right) q\left(\boldsymbol{\theta}^{o} \mid \boldsymbol{\theta}^{*}\right)}{p\left(\boldsymbol{\theta}^{o} \mid \mathbb{Y}\right) q\left(\boldsymbol{\theta}^{*} \mid \boldsymbol{\theta}^{o}\right)}\right\}
$$

The gradient and the Hessian are computed using analytic derivatives provided by computer algebra software. All computations are performed in Fortran 77 making extensive use of IMSL subroutines. 
The Metropolis-Hastings procedure we use is a simple random walk whose candidate generating density is a multivariate Student- $t$ distribution with 5 degrees of freedom ${ }^{7}$ and covariance equal to a scaled version of the covariance obtained from the Langevin Diffusion MCMC. The scale parameter is adjusted so that approximately $25 \%$ of the draws are accepted. The performance of Langevin Diffusion MCMC turns out to be vastly superior relative to the random-walk Metropolis-Hastings procedure (full details are available on request from the authors).

\section{B. Empirical Appendix: Country Specific Empirical Results}

This Appendix presents Tables B1-B5 which show country specific empirical results of the multivariate threshold PVECM employed in this paper. In particular, the results of Table B1 obtained from the estimation of a panel of 23 EU countries using "food" price indices at the farm, processor and retail levels; the results of Table B2 obtained from the estimation of a panel of 12 EU countries using "cereals and bread" price indices; the results Table B3 obtained from a panel of 14 EU countries using "meat" price indices; the results of Table B4 obtained from a panel of 10 EU countries using "milk, cheese and eggs" price indices; while those of Table B5 obtained from a panel of 8 EU countries using "oils and fats" price indices.

\footnotetext{
${ }^{7}$ This guarantees the existence of moments up to order four.
} 
Table B1: Food: country specific model (2005:01-1016:09)

\begin{tabular}{|c|c|c|c|c|c|c|c|c|c|c|c|c|c|c|c|c|c|c|c|c|c|c|c|}
\hline & $\mathrm{BE}$ & BG & $\mathrm{CZ}$ & DK & $\mathrm{DE}$ & $\mathrm{IE}$ & EL & ES & $F R$ & $\mathrm{HR}$ & IT & LT & $\mathrm{HU}$ & NL & AT & $\mathrm{PL}$ & PT & RO & $\mathrm{SI}$ & SK & $\mathrm{FI}$ & SE & UK \\
\hline \multicolumn{24}{|l|}{ Farm to Producer } \\
\hline \multicolumn{24}{|l|}{ Estimated Coefficients } \\
\hline$\rho$ & $\begin{array}{l}-0.223 \\
(0.006)\end{array}$ & $\begin{array}{l}-0.303 \\
(0.009)\end{array}$ & $\begin{array}{l}-0.203 \\
(0.011)\end{array}$ & $\begin{array}{l}-0.228 \\
(0.005)\end{array}$ & $\begin{array}{l}-0.183 \\
(0.010)\end{array}$ & $\begin{array}{l}-0.175 \\
(0.010)\end{array}$ & $\begin{array}{l}-0.357 \\
(0.007)\end{array}$ & $\begin{array}{l}-0.308 \\
(0.011)\end{array}$ & $\begin{array}{l}-0.256 \\
(0.006)\end{array}$ & $\begin{array}{l}-0.273 \\
(0.008\end{array}$ & $\begin{array}{l}-0.346 \\
(0.009)\end{array}$ & $\begin{array}{l}-0.194 \\
(0.006)\end{array}$ & $\begin{array}{l}-0.063 \\
(0.006)\end{array}$ & $\begin{array}{l}-0.168 \\
(0.009)\end{array}$ & $\begin{array}{l}-0.299 \\
(0.010)\end{array}$ & $\begin{array}{l}-0.090 \\
(0.010)\end{array}$ & $\begin{array}{l}-0.274 \\
(0.003)\end{array}$ & $\begin{array}{l}-0.075 \\
(0.005)\end{array}$ & $\begin{array}{l}-0.288 \\
(0.005)\end{array}$ & $\begin{array}{l}-0.142 \\
(0.005)\end{array}$ & $\begin{array}{l}-0.124 \\
(0.004)\end{array}$ & $\begin{array}{l}-0.190 \\
(0.004)\end{array}$ & $\begin{array}{l}-0.237 \\
(0.011)\end{array}$ \\
\hline$\alpha^{+}$ & $\begin{array}{l}0.851 \\
0.019)\end{array}$ & $\begin{array}{l}0.819 \\
(0.020)\end{array}$ & $\begin{array}{l}1.151 \\
(0.021)\end{array}$ & $\begin{array}{l}0.840 \\
0.016\end{array}$ & $\begin{array}{l}0.878 \\
0.012)\end{array}$ & $\begin{array}{l}0.841 \\
(0.020)\end{array}$ & $\begin{array}{l}0.814 \\
(0.014)\end{array}$ & $\begin{array}{l}0.848 \\
(0.020)\end{array}$ & $\begin{array}{l}1.128 \\
(0.019)\end{array}$ & $\begin{array}{l}0.942 \\
(0.013)\end{array}$ & $\begin{array}{l}0.771 \\
0.015\end{array}$ & $\begin{array}{l}1.088 \\
0.012\end{array}$ & $\begin{array}{l}1.136 \\
0.016\end{array}$ & $\begin{array}{l}1.026 \\
0.018\end{array}$ & $\begin{array}{l}0.847 \\
0.012)\end{array}$ & $\begin{array}{l}0.852 \\
(0.013)\end{array}$ & $\begin{array}{l}0.824 \\
0.019\end{array}$ & $\begin{array}{l}1.120 \\
0.015\end{array}$ & $\begin{array}{l}0.005) \\
0.912 \\
0.018\end{array}$ & $\begin{array}{l}(0.005) \\
0.959 \\
0.015)\end{array}$ & $\begin{array}{l}(0.0046) \\
0.916 \\
0.015)\end{array}$ & $\begin{array}{l}(0.0047) \\
1.047 \\
.0020)\end{array}$ & $\begin{array}{l}0.058 \\
0.858 \\
(0.018)\end{array}$ \\
\hline$\alpha^{-}$ & 0.823 & 0.797 & 1.116 & 0.817 & 0.844 & 0.810 & 0.797 & 0.814 & $\begin{array}{l}0.101 \\
1.01\end{array}$ & 0.911 & 0.742 & $\begin{array}{l}10.067 \\
\end{array}$ & 1.118 & 0.993 & 0.815 & 0.836 & 0.806 & $\begin{array}{l}1.092 \\
0\end{array}$ & 0.880 & 0.941 & 0.889 & 1.014 & $\begin{array}{l}(0.018) \\
0.827\end{array}$ \\
\hline & $(0.010)$ & $(0.007)$ & $(0.009)$ & $(0.007)$ & $(0.007)$ & $(0.009)$ & $(0.010)$ & $(0.009)$ & $(0.007)$ & $(0.008)$ & $(0.008)$ & $(0.007)$ & $(0.010)$ & $(0.009)$ & $(0.008)$ & $(0.010)$ & $(0.010)$ & $(0.010)$ & $(0.008)$ & $(0.009)$ & $(0.010)$ & $(0.006)$ & $(0.007)$ \\
\hline$\pi_{0}^{+}$ & $\begin{array}{l}0.384 \\
(0.006)\end{array}$ & $\begin{array}{l}0.329 \\
(0.011)\end{array}$ & $\begin{array}{l}0.153 \\
(0.011)\end{array}$ & $\begin{array}{l}0.399 \\
(0.009)\end{array}$ & $\begin{array}{l}0.365 \\
(0.009)\end{array}$ & $\begin{array}{l}0.350 \\
(0.008)\end{array}$ & $\begin{array}{l}0.352 \\
(0.008)\end{array}$ & $\begin{array}{l}0.406 \\
(0.008)\end{array}$ & $\begin{array}{l}0.326 \\
(0.006)\end{array}$ & $\begin{array}{l}0.470 \\
(0.006)\end{array}$ & $\begin{array}{l}0.243 \\
(0.009)\end{array}$ & $\begin{array}{l}0.363 \\
(0.008)\end{array}$ & $\begin{array}{l}0.365 \\
(0.008)\end{array}$ & $\begin{array}{l}0.506 \\
(0.012)\end{array}$ & $\begin{array}{l}0.175 \\
(0.007\end{array}$ & $\begin{array}{l}0.526 \\
(0.008)\end{array}$ & $\begin{array}{l}0.249 \\
(0.006)\end{array}$ & $\begin{array}{l}0.418 \\
(0.013\end{array}$ & 0.386 & $\begin{array}{l}0.463 \\
(0.010)\end{array}$ & 0.275 & 0.339 & $\begin{array}{l}0.191 \\
(0.005)\end{array}$ \\
\hline$\pi_{0}^{-}$ & 0.365 & 0.313 & 0.139 & 0.389 & 0.355 & 0.333 & 0.334 & 0.392 & 0.309 & 0.457 & 0.229 & 0.345 & 0.352 & 0.487 & 0.155 & 0.508 & 0.238 & 0.401 & 0.368 & 0.444 & 0.256 & 0.325 & $\begin{array}{l}(0.005) \\
0.175\end{array}$ \\
\hline$\sum_{i=1}^{q-1} \pi_{j}^{+}$ & $\begin{array}{l}(0.006) \\
0.616 \\
(0.025)\end{array}$ & $\begin{array}{l}(0.005) \\
0.797 \\
(0.024)\end{array}$ & $\begin{array}{l}(0.004) \\
0.321 \\
(0.021)\end{array}$ & $\begin{array}{l}(0.004) \\
0.906 \\
(0.025)\end{array}$ & $\begin{array}{l}(0.005) \\
0.284 \\
(0.026)\end{array}$ & $\begin{array}{l}(0.003) \\
0.250 \\
(0.024)\end{array}$ & $\begin{array}{l}(0.006) \\
0.859 \\
(0.016)\end{array}$ & $\begin{array}{l}(0.005) \\
0.324 \\
(0.021)\end{array}$ & $\begin{array}{l}(0.006) \\
0.877 \\
(0.015)\end{array}$ & $\begin{array}{l}(0.005) \\
0.916 \\
(0.021)\end{array}$ & $\begin{array}{l}(0.006) \\
0.704 \\
(0.029)\end{array}$ & $\begin{array}{l}(0.006) \\
0.848 \\
(0.022)\end{array}$ & $\begin{array}{l}(0.006) \\
0.312 \\
(0.034\end{array}$ & $\begin{array}{l}(0.006) \\
0.204 \\
(0.019)\end{array}$ & $\begin{array}{l}(0.006) \\
0.267 \\
(0.031)\end{array}$ & $\begin{array}{l}(0.005) \\
0.448 \\
(0.028)\end{array}$ & $\begin{array}{l}(0.006) \\
0.605 \\
(0.025)\end{array}$ & $\begin{array}{l}(0.006) \\
0.258 \\
(0.018)\end{array}$ & $\begin{array}{l}(0.005) \\
0.475 \\
(0.033)\end{array}$ & $\begin{array}{l}(0.005) \\
0.775 \\
(0.015)\end{array}$ & $\begin{array}{l}(0.003) \\
0.708 \\
(0.025)\end{array}$ & $\begin{array}{l}(0.003) \\
0.806 \\
(0.020)\end{array}$ & $\begin{array}{l}(0.005) \\
0.661 \\
(0.018)\end{array}$ \\
\hline$\sum_{j=1}^{q-1} \pi_{j}^{-}$ & $\begin{array}{l}0.604 \\
(0.015)\end{array}$ & $\begin{array}{l}0.785 \\
(0.013)\end{array}$ & $\begin{array}{l}0.309 \\
(0.011)\end{array}$ & $\begin{array}{l}0.896 \\
(0.017)\end{array}$ & $\begin{array}{l}0.266 \\
(0.015)\end{array}$ & $\begin{array}{l}0.238 \\
(0.008)\end{array}$ & $\begin{array}{l}0.847 \\
(0.006)\end{array}$ & $\begin{array}{l}0.308 \\
(0.008)\end{array}$ & $\begin{array}{l}0.861 \\
(0.015)\end{array}$ & $\begin{array}{l}0.905 \\
(0.014)\end{array}$ & $\begin{array}{l}0.693 \\
(0.011)\end{array}$ & $\begin{array}{l}0.831 \\
(0.015)\end{array}$ & $\begin{array}{l}0.296 \\
(0.017)\end{array}$ & $\begin{array}{l}0.192 \\
(0.008)\end{array}$ & $\begin{array}{l}0.250 \\
(0.016)\end{array}$ & $\begin{array}{l}0.429 \\
(0.011)\end{array}$ & $\begin{array}{l}0.588 \\
(0.010)\end{array}$ & $\begin{array}{l}0.240 \\
(0.010)\end{array}$ & $\begin{array}{l}0.458 \\
(0.007)\end{array}$ & $\begin{array}{l}0.763 \\
(0.016)\end{array}$ & $\begin{array}{l}0.692 \\
(0.011)\end{array}$ & $\begin{array}{l}0.787 \\
(0.009)\end{array}$ & $\begin{array}{l}0.649 \\
(0.015)\end{array}$ \\
\hline \multirow{2}{*}{\multicolumn{24}{|c|}{$\begin{array}{l}0.0085 \\
(0.0003)\end{array}$}} \\
\hline & & & & & & & & & & & & & & & & & & & & & & & \\
\hline$H_{0}: \alpha^{+}=\alpha^{-}$ & 54.83 & 32.66 & 61.89 & 67.14 & 67.88 & 52.12 & 29.78 & 41.31 & 47.99 & 15.38 & 18.23 & 33.03 & 58.22 & 38.75 & 68.78 & 34.89 & 60.74 & 51.93 & 32.00 & 67.84 & 42.90 & 41.55 & 47.54 \\
\hline$H_{0}: \pi_{0}^{+}=\pi_{0}^{-}$ & 74.14 & 65.19 & 67.94 & 68.51 & 66.53 & 70.83 & 67.90 & 83.64 & 67.74 & 51.48 & 73.26 & 74.00 & 62.92 & 70.01 & 60.27 & 70.46 & 73.69 & 61.134 & 54.11 & 63.10 & 81.37 & 83.50 & 70.40 \\
\hline$H_{0}: \sum_{j=1}^{q-1} \pi_{j}^{+}=\sum_{j=1}^{q-1} \pi_{j}^{-}$ & 54.41 & 59.76 & 87.83 & 61.05 & 65.77 & 90.34 & 67.46 & 52.75 & 84.34 & 79.08 & 55.31 & 66.10 & 58.56 & 54.04 & 78.61 & 78.65 & 83.37 & 71.29 & 52.17 & 53.96 & 52.63 & 80.14 & 55.57 \\
\hline \multicolumn{24}{|c|}{ Long--run relationship, using Bayes Factor } \\
\hline$\rho=0$ & 138.6 & 107.9 & 112.4 & 120.3 & 77.53 & 123.1 & 109.7 & 137.9 & 91.34 & 130.6 & 137.7 & 121.6 & 123.1 & 83.65 & 123.7 & 126.8 & 115.9 & 84.05 & 119.3 & 89.03 & 146.1 & 142.6 & 89.80 \\
\hline$\rho=\delta^{+}=\delta^{-}$ & 196.0 & 196.0 & 236.3 & 227.2 & 210.9 & 231.1 & 249.4 & 178.1 & 181.5 & 241.9 & 178.8 & 193.7 & 245.9 & 182.5 & 232.6 & 218.6 & 215.7 & 243.9 & 227.5 & 201.2 & 190.6 & 218.1 & 210.2 \\
\hline \multicolumn{24}{|l|}{ Producer to Co } \\
\hline \multicolumn{24}{|l|}{ Estimated } \\
\hline$\rho$ & $\begin{array}{l}-0.060 \\
(0.007)\end{array}$ & $\begin{array}{l}-0.278 \\
(0.006)\end{array}$ & $\begin{array}{l}-0.069 \\
(0.010)\end{array}$ & $\begin{array}{l}-0.260 \\
(0.010)\end{array}$ & $\begin{array}{l}-0.320 \\
(0.007)\end{array}$ & $\begin{array}{l}-0.249 \\
(0.006)\end{array}$ & $\begin{array}{l}-0.316 \\
(0.004)\end{array}$ & $\begin{array}{l}-0.159 \\
(0.006)\end{array}$ & $\begin{array}{l}-0.163 \\
(0.004)\end{array}$ & $\begin{array}{l}-0.329 \\
(0.004)\end{array}$ & $\begin{array}{l}-0.206 \\
(0.007)\end{array}$ & $\begin{array}{l}-0.237 \\
(0.004)\end{array}$ & $\begin{array}{l}-0.150 \\
(0.006)\end{array}$ & $\begin{array}{l}-0.161 \\
(0.011)\end{array}$ & $\begin{array}{l}-0.115 \\
(0.004)\end{array}$ & $\begin{array}{l}-0.064 \\
(0.010)\end{array}$ & $\begin{array}{l}-0.276 \\
(0.011)\end{array}$ & $\begin{array}{l}-0.110 \\
(0.010)\end{array}$ & $\begin{array}{l}-0.126 \\
(0.006)\end{array}$ & $\begin{array}{l}-0.232 \\
(0.007)\end{array}$ & $\begin{array}{l}-0.183 \\
(0.004)\end{array}$ & $\begin{array}{l}-0.306 \\
(0.007)\end{array}$ & $\begin{array}{l}-0.117 \\
(0.006)\end{array}$ \\
\hline$\alpha^{+}$ & $\begin{array}{l}0.818 \\
0.818\end{array}$ & 0.754 & $\begin{array}{l}1.065 \\
1.065\end{array}$ & 0.889 & $\begin{array}{l}0.856 \\
0.856\end{array}$ & $\begin{array}{l}0.834 \\
0.44\end{array}$ & $\begin{array}{l}0.985 \\
0.918\end{array}$ & 0.920 & $\begin{array}{l}0.934 \\
0.934\end{array}$ & $\begin{array}{l}1.00 \\
1.00\end{array}$ & $\begin{array}{l}0.957 \\
0.9570\end{array}$ & $\begin{array}{l}0.868 \\
0.86\end{array}$ & 1.093 & $\begin{array}{l}1.121 \\
1.121\end{array}$ & $\begin{array}{l}1.013 \\
1.013\end{array}$ & 0.874 & 0.896 & $\begin{array}{l}0.851 \\
0.851\end{array}$ & $\begin{array}{l}0.779 \\
0.7914)\end{array}$ & $\begin{array}{l}1.107 \\
0.016\end{array}$ & 0.918 & 1.058 & $\begin{array}{l}0.795 \\
0.019\end{array}$ \\
\hline$\alpha^{-}$ & 0.791 & 0.739 & 1.030 & 0.864 & 0.834 & 0.817 & 0.957 & 0.901 & $\begin{array}{l}(0.019) \\
0.912\end{array}$ & $\begin{array}{l}(0.013) \\
0.971\end{array}$ & 0.936 & $\begin{array}{l}(0.019) \\
0.852\end{array}$ & $\begin{array}{l}(0.020) \\
1.072\end{array}$ & $\begin{array}{l}(0.013) \\
1.094-251\end{array}$ & $\begin{array}{l}(0.021) \\
0.079\end{array}$ & $\begin{array}{l}(0.019) \\
0.839\end{array}$ & $\begin{array}{l}(0.019) \\
0.868-25\end{array}$ & $\begin{array}{l}(0.021) \\
0.819\end{array}$ & $\begin{array}{l}(0.014) \\
0.764\end{array}$ & $\begin{array}{l}(0.016) \\
1.082\end{array}$ & $\begin{array}{l}(0.016) \\
0.886\end{array}$ & $\begin{array}{l}(0.016) \\
1.036\end{array}$ & $\begin{array}{l}(0.019) \\
0.762\end{array}$ \\
\hline & $(0.007)$ & $(0.009)$ & $(0.008)$ & $(0.007)$ & $\begin{array}{l}.0 .009) \\
(0.009)\end{array}$ & $\begin{array}{l}.007) \\
(0.008)\end{array}$ & $\begin{array}{l}.0 .010) \\
(0.010-10\end{array}$ & $(0.007)$ & $(0.010)$ & $(0.007)$ & $\begin{array}{l}.0 .006) \\
(0.006-10\end{array}$ & $\begin{array}{l}.0 .028 \\
(0.008)\end{array}$ & $(0.010)$ & $(0.006)$ & $\begin{array}{l}(0.008) \\
(0.0)\end{array}$ & $\begin{array}{l}.0 .008) \\
(0.008)\end{array}$ & $\begin{array}{l}\text { (0.868 } \\
(0.010)\end{array}$ & $\begin{array}{l}0.8 .009) \\
(0.09)\end{array}$ & $\begin{array}{l}0.164 \\
(0.010)\end{array}$ & $\begin{array}{l}1.082 \\
(0.007)\end{array}$ & $\begin{array}{l}0.886 \\
(0.007)\end{array}$ & $\begin{array}{l}1.036 \\
(0.010)\end{array}$ & $\begin{array}{l}0.102 \\
(0.010)\end{array}$ \\
\hline$\pi_{0}^{+}$ & 0.431 & 0.470 & 0.430 & 0.363 & 0.262 & 0.424 & 0.168 & 0.187 & 0.473 & 0.170 & 0.314 & 0.4637 & 0.504 & 0.502 & 0.433 & 0.448 & 0.345 & 0.379 & 0.184 & 0.255 & 0.457 & 0.210 & 0.497 \\
\hline & $(0.010)$ & $(0.011)$ & $(0.008)$ & $(0.011)$ & $(0.005)$ & $(0.008)$ & $(0.010)$ & $(0.011)$ & $(0.012)$ & $(0.011)$ & $(0.012)$ & $(0.010)$ & $(0.013)$ & $(0.009)$ & $(0.011)$ & $(0.007)$ & $(0.006)$ & $(0.008)$ & $(0.009)$ & $(0.013)$ & $(0.006)$ & $(0.008)$ & $(0.013)$ \\
\hline$\pi_{0}^{-}$ & 0.413 & 0.453 & 0.411 & 0.345 & 0.242 & 0.412 & 0.151 & 0.176 & 0.461 & 0.158 & 0.296 & 0.451 & 0.494 & 0.487 & 0.418 & 0.437 & 0.332 & 0.365 & 0.173 & 0.241 & 0.442 & 0.194 & 0.478 \\
\hline & $(0.005)$ & $(0.002)$ & $(0.005)$ & $(0.004)$ & $(0.002)$ & $\begin{array}{l}(0.002) \\
0318\end{array}$ & $\begin{array}{l}(0.005) \\
0290\end{array}$ & $(0.006)$ & $(0.003)$ & $(0.004)$ & $(0.005)$ & $(0.005)$ & $(0.006)$ & $(0.004)$ & $(0.004)$ & $(0.005)$ & $(0.005)$ & $(0.006)$ & $(0.004)$ & $(0.002)$ & $(0.006)$ & $(0.004)$ & $(0.003)$ \\
\hline$\sum_{j=1}^{q-1} \pi_{j}^{+}$ & $\begin{array}{l}0.627 \\
(0.017)\end{array}$ & $\begin{array}{l}0.1 / 33 \\
(0.016)\end{array}$ & $\begin{array}{l}0.894 \\
(0.019)\end{array}$ & $\begin{array}{l}0.240 \\
(0.023)\end{array}$ & $\begin{array}{l}0.447 \\
(0.013)\end{array}$ & $\begin{array}{l}0.318 \\
(0.029)\end{array}$ & $\begin{array}{l}0.290 \\
(0.024)\end{array}$ & $\begin{array}{l}0.406 \\
(0.025)\end{array}$ & $\begin{array}{l}0.831 \\
(0.014)\end{array}$ & $\begin{array}{l}0.466 \\
(0.020)\end{array}$ & $\begin{array}{l}0.866 \\
(0.023)\end{array}$ & $\begin{array}{l}0.168 \\
(0.014)\end{array}$ & $\begin{array}{l}0.749 \\
(0.021)\end{array}$ & $\begin{array}{l}0.236 \\
(0.024)\end{array}$ & $\begin{array}{l}0.387 \\
(0.015)\end{array}$ & $\begin{array}{l}0.209 \\
(0.013)\end{array}$ & $\begin{array}{l}0.693 \\
(0.030)\end{array}$ & $\begin{array}{l}0.304 \\
(0.032)\end{array}$ & $\begin{array}{l}0.592 \\
(0.025)\end{array}$ & $\begin{array}{l}0.560 \\
(0.017)\end{array}$ & $\begin{array}{l}0.371 \\
(0.028)\end{array}$ & $\begin{array}{l}0.582 \\
(0.023)\end{array}$ & $\begin{array}{l}0.570 \\
(0.030)\end{array}$ \\
\hline$\sum^{q-1} \pi_{j}^{-}$ & $\begin{array}{l}0.616 \\
(0.017)\end{array}$ & $\begin{array}{l}0.734 \\
(0.013)\end{array}$ & $\begin{array}{l}0.880 \\
0.007)\end{array}$ & $\begin{array}{l}0.229 \\
0.014)\end{array}$ & $\begin{array}{l}0.429 \\
0.009)\end{array}$ & $\begin{array}{l}0.301 \\
(0.012)\end{array}$ & 0.272 & $\begin{array}{l}0.392 \\
(0.013)\end{array}$ & $\begin{array}{l}0.818 \\
0.006)\end{array}$ & 0.438 & $\begin{array}{l}0.850 \\
0.011)\end{array}$ & $\begin{array}{l}0.756 \\
0.017)\end{array}$ & $\begin{array}{l}0.739 \\
0.015)\end{array}$ & 0.221 & 0.371 & 0.197 & 0.683 & 0.288 & 0.576 & 0.548 & 0.354 & 0.571 & 0.553 \\
\hline$\lambda^{i=1}$ & & & & & & & & & & & & & & & & & & & & $(0.013)$ & $(0.006)$ & $(0.015)$ & \\
\hline \multicolumn{24}{|c|}{$\begin{array}{l}0.0073 \\
(0.0002)\end{array}$} \\
\hline $\begin{array}{l}\text { Symm } \\
H_{0}: \alpha\end{array}$ & Factor & & & & & & & & & & & & & & & & & & & & & & \\
\hline$H_{0}: \alpha$ & 53.21 & 46.01 & 51.24 & 57.11 & 56.43 & 33.63 & 69.70 & 38.42 & 65.75 & 32.99 & 61.65 & 47.93 & 14.71 & 67.16 & 47.72 & 61.60 & 57.24 & 64.16 & 36.41 & 52.29 & 18.08 & 55.85 & 20.03 \\
\hline$H_{0}: \pi_{0}^{+}=\pi_{0}^{-}$ & 82.25 & 69.91 & 52.78 & 51.63 & 83.55 & 82.66 & 49.15 & 78.01 & 65.05 & 62.24 & 58.37 & 57.10 & 73.16 & 66.65 & 79.19 & 48.99 & 63.27 & 61.77 & 70.01 & 49.74 & 74.28 & 78.73 & 67.07 \\
\hline$H_{0}: \sum_{j=1}^{q-1} \pi_{j}^{+}=\sum_{j=1}^{q-1} \pi_{j}^{-}$ & 60.67 & 71.58 & 76.62 & 86.58 & 52.16 & 66.42 & 67.87 & 71.06 & 71.40 & 69.31 & 61.52 & 63.76 & 83.88 & 88.96 & 87.24 & 86.08 & 61.21 & 74.58 & 76.41 & 59.29 & 68.00 & 74.43 & 56.80 \\
\hline \multicolumn{24}{|c|}{ Long-run relationship, using Bayes' Factor } \\
\hline & 98.66 & 95.75 & 151. & 118.1 & 79.57 & 123 & 152 & 144 & 127. & 118 & 144 & 107 & 123 & 144 & 152 & 81. & 81. & 102 & 93. & 135 & 15 & 135.4 & 149.6 \\
\hline$\rho=\delta^{+}=\delta^{-}$ & 252.4 & 254.2 & 200.4 & 189.3 & 215.0 & 196.2 & 208.3 & 245.9 & 209.6 & 234.3 & 186.2 & 182.9 & 244.6 & 185.2 & 185.2 & 214.9 & 215.5 & 198.4 & 211.5 & 214.7 & 178.0 & 239.8 & 250.4 \\
\hline
\end{tabular}

Notes: Estimated coefficients report posterior means and posterior standard deviations of the most important parameters of the model.

BEstands for Belgium; BG stands for Bulgaria; CZ stands for the Czech Republic; DK stands forDenmark; DEstands for Germany; IEstands for Ireland; ELstands for Greece; ESstands for Spain; FR stands forFrance; HR

stands forCroatia; IT stands forltaly; LT stands forLithuania; HU stands forHungary; NL stands forNetherlands; AT stands forAustria; PL stands forPoland; PT stands forPortugal;RO stands forRomania;SI stands

forSlovenia; SK stands forSlovakia; Flstands for Finland; SE stands forSweden; UK stands forthe United Kingdom. 
Table B2: Cereals and Bread: country specific model (2005:01-1016:09)

\begin{tabular}{|c|c|c|c|c|c|c|c|c|c|c|c|c|}
\hline 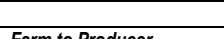 & Bulgaria & Germany & Greece & Spain & France & Croatia & Italy & Hungary & Netherland & Poland & $\begin{array}{l}\text { Portugal } \\
\end{array}$ & UK \\
\hline \multicolumn{13}{|l|}{ Farm to Producer } \\
\hline \multicolumn{13}{|l|}{ Estimated Coefficients } \\
\hline$\rho$ & -0.275 & -0.336 & -0.151 & -0.347 & -0.251 & -0.265 & -0.227 & -0.188 & -0.101 & -0.344 & -0.318 & -0.291 \\
\hline & $(0.008)$ & $(0.004)$ & $(0.007)$ & $(0.004)$ & $(0.005)$ & $(0.004)$ & $(0.009)$ & $(0.005)$ & $(0.007)$ & $(0.009)$ & $(0.011)$ & $(0.003)$ \\
\hline$\alpha^{+}$ & $\begin{array}{l}0.971 \\
(0.017)\end{array}$ & $\begin{array}{l}1.086 \\
.0014)\end{array}$ & $\begin{array}{l}0.782 \\
(0.014)\end{array}$ & $\begin{array}{l}0.760 \\
(0.021)\end{array}$ & $\begin{array}{l}0.905 \\
(0.015)\end{array}$ & $\begin{array}{l}1.068 \\
(0.020)\end{array}$ & $\begin{array}{l}0.835 \\
(0.016)\end{array}$ & $\begin{array}{l}0.920 \\
0.016\end{array}$ & $\begin{array}{l}0.854 \\
(0.014)\end{array}$ & $\begin{array}{l}0.865 \\
(0.018)\end{array}$ & $\begin{array}{l}0.811 \\
(0.013)\end{array}$ & 1.101 \\
\hline$\alpha^{-}$ & 0.936 & $\begin{array}{l}(0.014) \\
1.057\end{array}$ & 0.750 & 0.729 & 0.872 & $\begin{array}{l}0.020) \\
1.037\end{array}$ & 0.816 & 0.897 & $\begin{array}{l}(0.014) \\
0.825\end{array}$ & $\begin{array}{l}(0.018) \\
0.842\end{array}$ & $\begin{array}{l}(0.0173) \\
0.776\end{array}$ & $\begin{array}{l}(0.013) \\
1085\end{array}$ \\
\hline & $(0.008)$ & $(0.010)$ & $\begin{array}{l}.0 .007) \\
(0.007\end{array}$ & $\begin{array}{l}0.010) \\
(0.010\end{array}$ & $\begin{array}{l}.0006) \\
(0.006)\end{array}$ & $(0.007)$ & $\begin{array}{l}.0 .008) \\
(0.008\end{array}$ & $(0.008)$ & $\begin{array}{l}0.820 \\
(0.009)\end{array}$ & $\begin{array}{l}0.042 \\
(0.008)\end{array}$ & $(0.008)$ & $\begin{array}{l}1.085 \\
(0.008)\end{array}$ \\
\hline$\pi_{0}^{+}$ & 0.199 & 0.312 & 0.260 & 0.401 & 0.188 & 0.451 & 0.344 & 0.148 & 0.276 & 0.321 & 0.458 & 0.438 \\
\hline & $(0.010)$ & $(0.006)$ & $(0.011)$ & $(0.009)$ & $(0.012)$ & $(0.010)$ & $(0.005)$ & $(0.005)$ & $(0.010)$ & $(0.005)$ & $(0.013)$ & $(0.007)$ \\
\hline$\pi_{0}^{-}$ & 0.182 & 0.300 & 0.247 & 0.385 & 0.177 & 0.437 & 0.332 & 0.129 & 0.266 & 0.306 & 0.448 & 0.420 \\
\hline & & $(0.003)$ & $(0.006)$ & $(0.004)$ & $(0.004$ & $(0.003$ & $(0.002)$ & $(0.006)$ & $(0.003)$ & $(0.004)$ & $(0.003$ & $(0.005)$ \\
\hline$\sum_{j=1}^{q-1} \pi_{j}^{+}$ & $\begin{array}{l}0.652 \\
(0.016)\end{array}$ & $\begin{array}{l}0.759 \\
(0.019)\end{array}$ & $\begin{array}{l}0.904 \\
(0.027)\end{array}$ & $\begin{array}{l}0.282 \\
(0.021)\end{array}$ & $\begin{array}{l}0.590 \\
(0.031\end{array}$ & $\begin{array}{l}0.333 \\
(0.015)\end{array}$ & $\begin{array}{l}0.811 \\
(0.025)\end{array}$ & $\begin{array}{l}0.508 \\
(0.016)\end{array}$ & $\begin{array}{l}0.914 \\
(0.031)\end{array}$ & $\begin{array}{l}0.872 \\
(0.015)\end{array}$ & $\begin{array}{l}0.657 \\
(0.015)\end{array}$ & $\begin{array}{l}0.462 \\
(0.025)\end{array}$ \\
\hline$\sum^{q-1} \pi^{-}$ & 0.637 & 0.739 & 0.888 & 0.264 & 0.577 & 0.323 & 0.793 & 0.495 & 0.902 & 0.853 & 0.642 & 0.446 \\
\hline$\sum_{j=1}^{\pi_{j}}$ & $(0.014)$ & $(0.009)$ & $(0.006)$ & $(0.010)$ & $(0.006)$ & $(0.011)$ & $(0.006)$ & $(0.013)$ & $(0.011)$ & $(0.016)$ & $(0.010)$ & $(0.010)$ \\
\hline$\lambda$ & & & & & & $\begin{array}{l}0.0061 \\
(0.0009)\end{array}$ & & & & & & \\
\hline \multicolumn{13}{|c|}{ Symmetry tests, using Bayes' Factor } \\
\hline$H_{0}: \alpha^{+}=\alpha^{-}$ & 31.99 & 37.50 & 45.55 & 22.63 & 22.60 & 63.29 & 16.15 & 23.86 & 23.26 & 53.6 & 19.20 & 68.01 \\
\hline$H_{0}: \pi_{0}^{+}=\pi_{0}^{-}$ & 73.00 & 82.77 & 166.2 & 124.9 & 154.1 & 49.71 & 179.8 & 126.6 & 97.40 & 178.5 & 98.07 & 115.9 \\
\hline$H_{0}: \sum_{j=1}^{q-1} \pi_{j}^{+}=\sum_{j=1}^{q-1} \pi_{j}^{-}$ & 177.0 & 230.7 & 192.3 & 185.8 & 152.4 & 171.0 & 149.4 & 217.6 & 195.2 & 164.5 & 211.2 & 218.8 \\
\hline \multicolumn{13}{|c|}{ Long-run relationship, using Bayes' Factor } \\
\hline$\rho=0$ & 147.8 & 107.0 & 92.86 & 136.8 & 109.1 & 123.8 & 108.8 & 105.6 & 114.2 & 148.0 & 114.5 & 141.8 \\
\hline$\rho=\delta^{+}=\delta^{-}$ & 222.2 & 227.4 & 210.4 & 238.1 & 178.5 & 210.5 & 214.9 & 193.4 & 232.2 & 244.0 & 194.1 & 249.4 \\
\hline \multicolumn{13}{|l|}{ Producer to Consumer } \\
\hline \multicolumn{13}{|l|}{ Estimated Coefficients } \\
\hline$\rho$ & -0.283 & -0.138 & -0.247 & -0.262 & -0.224 & -0.078 & -0.229 & -0.164 & -0.204 & -0.176 & -0.128 & -0.185 \\
\hline & $(0.011)$ & $(0.008)$ & $(0.009)$ & $(0.006)$ & $(0.007)$ & $(0.008)$ & $(0.006)$ & $(0.005)$ & $(0.003)$ & $(0.010)$ & $(0.005)$ & $(0.011)$ \\
\hline$\alpha^{+}$ & $\begin{array}{l}1.145 \\
(0.019)\end{array}$ & $\begin{array}{l}1.043 \\
(0.021)\end{array}$ & $\begin{array}{l}0.940 \\
(0.018)\end{array}$ & $\begin{array}{l}0.868 \\
(0.012)\end{array}$ & $\begin{array}{l}0.970 \\
(0.014)\end{array}$ & $\begin{array}{l}1.094 \\
(0.014)\end{array}$ & $\begin{array}{l}0.948 \\
(0.012)\end{array}$ & $\begin{array}{l}0.933 \\
0.017)\end{array}$ & $\begin{array}{l}1.004 \\
(0.015)\end{array}$ & $\begin{array}{l}0.801 \\
(0.015)\end{array}$ & $\begin{array}{l}0.7516 \\
(0.016)\end{array}$ & $\begin{array}{l}1.007 \\
(0.013)\end{array}$ \\
\hline$\alpha^{-}$ & 1.119 & 1.022 & $\begin{array}{l}(0.018) \\
0.919\end{array}$ & $\begin{array}{l}(0.012) \\
0.837\end{array}$ & $\begin{array}{l}(0.014) \\
0.953\end{array}$ & $\begin{array}{l}(0.014) \\
1.073\end{array}$ & $\begin{array}{l}(0.012) \\
0.914\end{array}$ & $\begin{array}{l}(0.017) \\
0.909\end{array}$ & $\begin{array}{l}(0.015) \\
0.976\end{array}$ & $\begin{array}{l}(0.015) \\
0783\end{array}$ & $\begin{array}{l}(0.016) \\
0.0729\end{array}$ & $\begin{array}{l}(0.013) \\
0988\end{array}$ \\
\hline$a$ & $(0.009)$ & $\begin{array}{l}1.028 \\
(0.009)\end{array}$ & $\begin{array}{l}(0.007) \\
\text { (n) }\end{array}$ & $\begin{array}{l}.031 \\
(0.006)\end{array}$ & $\begin{array}{l}(0.008) \\
(0.00\end{array}$ & $(0.006)$ & $(0.008)$ & $(0.007$ & $(0.007)$ & $\begin{array}{l}.100 \\
(0.007)\end{array}$ & $\begin{array}{l}.0 / 29 \\
(0.010)\end{array}$ & $\begin{array}{l}0.988 \\
(0.007)\end{array}$ \\
\hline$\pi_{0}^{+}$ & 0.231 & 0.394 & 0.421 & 0.491 & 0.157 & 0.147 & 0.171 & 0.392 & 0.529 & 0.284 & 0.299 & $\begin{array}{l}(0.007) \\
0414\end{array}$ \\
\hline & $(0.007)$ & $(0.013)$ & $(0.009)$ & $(0.010)$ & $(0.005)$ & $(0.006)$ & $(0.005)$ & $(0.006)$ & $(0.012)$ & $(0.013)$ & $(0.010)$ & $\begin{array}{l}0.414 \\
(0005)\end{array}$ \\
\hline$\pi_{0}^{-}$ & 0.221 & 0.377 & 0.409 & 0.481 & 0.142 & 0.127 & 0.159 & 0.378 & 0.513 & 0.269 & 0.289 & $\begin{array}{l}(0.005) \\
0.401\end{array}$ \\
\hline & $(0.006)$ & $(0.003)$ & $(0.004)$ & $(0.003)$ & $(0.003)$ & $(0.004)$ & $(0.003$ & $(0.002)$ & $(0.004)$ & $(0.005)$ & $(0.004)$ & $\begin{array}{l}.401 \\
(0.006)\end{array}$ \\
\hline$\Gamma^{q-1}{ }^{+}$ & 0.876 & 0.821 & 0.475 & 0.864 & 0.808 & 0.661 & 0.912 & 0.215 & 0.457 & 0.747 & 0.530 & 0.556 \\
\hline$\sum_{j=1} \pi_{j}^{+}$ & $(0.024)$ & $(0.031)$ & $(0.017)$ & $(0.013)$ & $(0.023)$ & $(0.032)$ & $(0.033)$ & $(0.017)$ & $(0.015)$ & $(0.017)$ & $\begin{array}{l}(0.013) \\
(0.01\end{array}$ & $\begin{array}{l}(0.022) \\
\text { (a) }\end{array}$ \\
\hline$\sum_{\pi_{i}^{-}}^{q-1}$ & 0.861 & 0.810 & 0.462 & 0.848 & 0.790 & 0.641 & 0.896 & 0.201 & 0.441 & 0.732 & 0.515 & 0.537 \\
\hline$乙_{j=1}^{n_{j}}$ & $(0.007)$ & $(0.015)$ & $(0.006)$ & $(0.011)$ & $(0.006)$ & $(0.013)$ & $(0.016)$ & $(0.016)$ & $(0.010)$ & $(0.017)$ & $(0.017)$ & $(0.016)$ \\
\hline$\wedge$ & & & & & & 0.0068 & & & & & & \\
\hline \multicolumn{13}{|c|}{ Symmetry tests, using Bayes' Factor } \\
\hline$H_{0}: \alpha^{+}=\alpha^{-}$ & 51.18 & 37.26 & 68.29 & 14.06 & 62.66 & 45.62 & 13.78 & 62.82 & 66.72 & 42.91 & 35.86 & 56.09 \\
\hline$H_{0}: \pi_{0}^{+}=\pi_{0}^{-}$ & 96.69 & 166.95 & 153.04 & 89.44 & 90.79 & 116.60 & 180.21 & 114.1 & 48.96 & 157.5 & 158.4 & 146.1 \\
\hline$H_{0}: \sum_{j=1}^{q-1} \pi_{j}^{+}=\sum_{j=1}^{q-1} \pi_{j}^{-}$ & 173.2 & 232.3 & 152.1 & 198.2 & 226.2 & 202.1 & 170.4 & 163.0 & 232.5 & 157.9 & 150.4 & 217.1 \\
\hline \multicolumn{13}{|c|}{ Long-run relationship, using Bayes' Factor } \\
\hline & 131.9 & 86.87 & 80.37 & 146.8 & 136.1 & 127.2 & 132.4 & 109.4 & 91.46 & 77.88 & 109.9 & 106.0 \\
\hline$\rho=\delta^{+}=\delta^{-}$ & 232.9 & 248.9 & 238.1 & 201.7 & 237.2 & 189.7 & 179.2 & 197.2 & 203.6 & 209.0 & 191.1 & 245.2 \\
\hline
\end{tabular}

Notes: Estimated coefficients report posterior means and posterior standard deviations of the most important parameters of the model. 
Table B3: Meat: country specific model (2005:01-1016:09)

\begin{tabular}{|c|c|c|c|c|c|c|c|c|c|c|c|c|c|c|}
\hline & Bulgaria & Germany & Greece & Spain & France & Croatia & Italy & Hungary & Netherlands & Poland & Portugal & Slovenia & Sweden & UK \\
\hline \multirow{2}{*}{\multicolumn{15}{|c|}{ Farm to Producer }} \\
\hline & & & & & & & & & & & & & & Estimated Coefficients \\
\hline$\rho$ & -0.108 & $\begin{array}{l}-0.149 \\
-0.143)\end{array}$ & -0.125 & -0.153 & $\begin{array}{l}-0.192 \\
-0.196\end{array}$ & -0.353 & -0.187 & -0.081 & -0.095 & -0.083 & -0.332 & -0.078 & -0.232 & -0.134 \\
\hline$\alpha^{+}$ & $\begin{array}{l}(0.006) \\
0.756\end{array}$ & $\begin{array}{l}(0.003) \\
0.834\end{array}$ & $\begin{array}{l}(0.009) \\
1.067\end{array}$ & $\begin{array}{l}(0.005) \\
0.927\end{array}$ & $\begin{array}{l}(0.006) \\
0.798\end{array}$ & $\begin{array}{l}(0.005) \\
1.074\end{array}$ & $\begin{array}{l}(0.010) \\
0.802\end{array}$ & $\begin{array}{l}(0.003) \\
0.998\end{array}$ & $\begin{array}{l}(0.005) \\
1.091\end{array}$ & $\begin{array}{l}(0.011) \\
1.117\end{array}$ & $\begin{array}{l}(0.005) \\
0.951\end{array}$ & $\begin{array}{l}(0.005) \\
0.865\end{array}$ & $\begin{array}{l}(0.007) \\
0.743\end{array}$ & $(0.008)$ \\
\hline & $(0.018)$ & $\begin{array}{l}(0.019) \\
(0.019)\end{array}$ & $\begin{array}{l}(.0016) \\
(0.016)\end{array}$ & $\begin{array}{l}(0.017) \\
(927)\end{array}$ & $\begin{array}{l}(0.018) \\
(190)\end{array}$ & $\begin{array}{l}(.014 \\
(0.014\end{array}$ & $\begin{array}{l}0.002 \\
(0.015)\end{array}$ & $\begin{array}{l}0.998 \\
(0.021)\end{array}$ & $\begin{array}{l}1.091 \\
(0.012\end{array}$ & $\begin{array}{l}1.1717 \\
(0.018)\end{array}$ & $\begin{array}{l}0.551 \\
(0.017)\end{array}$ & $\begin{array}{l}0.865 \\
(0.012)\end{array}$ & $\begin{array}{l}0.143 \\
(0.017)\end{array}$ & $\begin{array}{l}0.800 \\
(0.021)\end{array}$ \\
\hline$\alpha^{-}$ & 0.739 & 0.803 & 1.046 & 0.910 & 0.774 & 1.049 & 0.787 & 0.982 & 1.057 & 1.098 & 0.933 & 0.837 & 0.728 & 0.853 \\
\hline & $(0.009)$ & $(0.006)$ & & $(0.008$ & $(0.010)$ & $(0.006)$ & $(0.006)$ & $(0.009)$ & $(0.008)$ & $(0.006)$ & $(0.007)$ & $(0.010)$ & $(0.009)$ & $(0.007)$ \\
\hline$\pi_{0}^{+}$ & 0.443 & 0.281 & 0.385 & 0.359 & 0.374 & 0.117 & 0.193 & 0.317 & 0.460 & 0.306 & 0.473 & 0.226 & 0.374 & 0.414 \\
\hline$\pi_{0}^{-}$ & 0.428 & 0.262 & 0.374 & 0.345 & $\begin{array}{l}(0.007) \\
0356\end{array}$ & $\begin{array}{l}(0.010) \\
0.102\end{array}$ & 0.173 & $\begin{array}{l}(0.006) \\
0305\end{array}$ & $\begin{array}{l}(0.008) \\
0.449\end{array}$ & $\begin{array}{l}(0.009) \\
0288\end{array}$ & (0.009) & $(0.005)$ & $(0.011)$ & $(0.010)$ \\
\hline$\pi_{0}$ & $\begin{array}{l}0.428 \\
(0.005)\end{array}$ & $\begin{array}{l}.202 \\
(0.005)\end{array}$ & $\begin{array}{l}0.034 \\
(0.006)\end{array}$ & $\begin{array}{l}.0 .35 \\
(0.005)\end{array}$ & $\begin{array}{l}.300 \\
(0.005)\end{array}$ & $\begin{array}{l}0.102 \\
(0.006)\end{array}$ & $\begin{array}{l}0.003) \\
(0.0035\end{array}$ & $\begin{array}{l}(0.003) \\
(305)\end{array}$ & $\begin{array}{l}0.449 \\
(0.006)\end{array}$ & $(0.005$ & $\begin{array}{l}0.451 \\
(0.006)\end{array}$ & $\begin{array}{l}0.209 \\
(0.005)\end{array}$ & $\begin{array}{l}0.006) \\
(0.006)\end{array}$ & $\begin{array}{l}0.400 \\
(0.006)\end{array}$ \\
\hline$\sum^{q-1} \pi_{i}^{+}$ & 0.890 & 0.897 & 0.900 & 0.708 & 0.327 & 0.702 & 0.834 & 0.615 & 0.866 & 0.919 & 0.724 & 0.253 & 0.654 & 0.297 \\
\hline$\sum_{j=1} \pi_{j}$ & $(0.024)$ & $(0.014)$ & $(0.031)$ & $(0.029)$ & $(0.032)$ & $(0.025)$ & $(0.030)$ & $(0.031)$ & $(0.018)$ & $(0.013)$ & $(0.029)$ & $(0.024)$ & $(0.018)$ & $(0.027)$ \\
\hline$\sum_{j=1}^{q-1} \pi_{j}^{-}$ & $\begin{array}{l}0.877 \\
(0.008)\end{array}$ & $\begin{array}{l}0.883 \\
(0.008)\end{array}$ & $\begin{array}{l}0.881 \\
(0.009)\end{array}$ & $\begin{array}{l}0.696 \\
(0.013)\end{array}$ & $\begin{array}{l}0.313 \\
(0.009)\end{array}$ & $\begin{array}{l}0.684 \\
(0.016)\end{array}$ & $\begin{array}{l}0.819 \\
(0.014)\end{array}$ & $\begin{array}{l}0.597 \\
(0.014)\end{array}$ & $\begin{array}{l}0.849 \\
(0.010)\end{array}$ & $\begin{array}{l}0.908 \\
(0.013)\end{array}$ & $\begin{array}{l}0.709 \\
(0.007)\end{array}$ & $\begin{array}{l}0.234 \\
(0.013)\end{array}$ & $\begin{array}{l}0.640 \\
(0.006)\end{array}$ & $\begin{array}{l}0.277 \\
(0.013)\end{array}$ \\
\hline \multirow{2}{*}{\multicolumn{15}{|c|}{ A }} \\
\hline & & & & & & & & & & & & & & \\
\hline$H_{0}: \alpha^{+}=\alpha^{-}$ & 45.54 & 14.30 & 40.86 & 64.35 & 59.80 & 37.77 & 49.37 & 52.41 & 14.92 & 23.49 & 53.50 & 69.60 & 35.78 & 53.71 \\
\hline$H_{0}: \pi_{0}^{+}=\pi_{0}^{-}$ & 68.65 & 81.76 & 63.97 & 66.63 & 79.81 & 59.80 & 69.39 & 53.50 & 55.40 & 52.58 & 69.15 & 59.87 & 69.51 & 74.14 \\
\hline$H_{0}: \sum_{j=1}^{q-1} \pi_{j}^{+}=\sum_{j=1}^{q-1} \pi_{j}^{-}$ & 69.94 & 69.27 & 57.05 & 58.44 & 79.95 & 67.61 & 59.24 & 59.04 & 81.53 & 66.62 & 78.41 & 56.84 & 76.27 & 86.60 \\
\hline \multicolumn{15}{|c|}{ Long-run relationship, using Bayes' Factor } \\
\hline$\rho=0$ & 122.1 & 91.95 & 87.49 & 142.8 & 99.77 & 105.1 & 129.7 & 92.98 & 106.0 & 145.5 & 152.3 & 81.99 & 134.7 & 78.58 \\
\hline$\rho=\delta^{+}=\delta^{-}$ & 234.9 & 188.3 & 182.7 & 216.1 & 221.0 & 186.0 & 185.4 & 230.0 & 199.4 & 237.3 & 235.9 & 230.3 & 180.3 & 193.1 \\
\hline \multirow{2}{*}{\multicolumn{15}{|c|}{ Producer to Consumer }} \\
\hline & \multicolumn{14}{|c|}{ Estimated Coefficients } \\
\hline$\rho$ & -0.283 & -0.327 & -0.147 & -0.303 & -0.219 & -0.106 & -0.243 & -0.327 & -0.112 & -0.297 & -0.314 & -0.083 & -0.289 & -0.135 \\
\hline & $(0.003)$ & $(0.008)$ & $(0.005)$ & $(0.004)$ & $(0.008)$ & $(0.003)$ & $(0.005)$ & $(0.004)$ & $(0.004)$ & $(0.008)$ & $(0.006)$ & $(0.003)$ & $(0.009)$ & $(0.005)$ \\
\hline$\alpha^{+}$ & $\begin{array}{l}0.894 \\
(0.014)\end{array}$ & $\begin{array}{l}0.906 \\
(0.017)\end{array}$ & $\begin{array}{l}0.750 \\
(0.015)\end{array}$ & $\begin{array}{l}0.739 \\
(0.014)\end{array}$ & $\begin{array}{l}0.773 \\
(0.019)\end{array}$ & $\begin{array}{l}0.774 \\
(0.019)\end{array}$ & $\begin{array}{l}0.965 \\
(0.016)\end{array}$ & $\begin{array}{l}0.968 \\
(0.018)\end{array}$ & $\begin{array}{l}0.918 \\
(0.018)\end{array}$ & $\begin{array}{l}1.020 \\
(0.021)\end{array}$ & $\begin{array}{l}0.833 \\
(0.013)\end{array}$ & $\begin{array}{l}1.142 \\
(0.021)\end{array}$ & $\begin{array}{l}0.984 \\
(0.020)\end{array}$ & $\begin{array}{l}0.842 \\
(0.019)\end{array}$ \\
\hline$\alpha^{-}$ & 0.870 & 0.890 & 0.723 & 0.759 & 0.756 & 0.752 & 0.949 & 0.949 & 0.901 & 0.989 & 0.807 & 1.117 & 0.963 & 0.825 \\
\hline & $(0.010)$ & $(0.008)$ & $(0.009)$ & $(0.007)$ & $(0.006)$ & $(0.007)$ & $(0.010)$ & $(0.008)$ & $(0.008)$ & $(0.006)$ & $(0.009)$ & $(0.008)$ & $(0.009)$ & $(0.009)$ \\
\hline$\pi_{0}^{+}$ & 0.399 & 0.246 & 0.208 & 0.280 & 0.289 & 0.417 & 0.471 & 0.297 & 0.477 & 0.459 & 0.184 & 0.469 & 0.445 & 0.117 \\
\hline & $(0.009)$ & $(0.008)$ & $(0.012)$ & $(0.007)$ & $(0.006)$ & $(0.005)$ & $(0.011)$ & $(0.006)$ & $(0.005)$ & $(0.005)$ & $(0.011)$ & $(0.012)$ & $0.007)$ & $(0.009)$ \\
\hline$\pi_{0}^{-}$ & 0.384 & 0.233 & 0.190 & 0.264 & 0.272 & 0.398 & 0.457 & 0.285 & 0.461 & 0.441 & 0.171 & 0.451 & 0.431 & 0.106 \\
\hline & $(0.010)$ & $(0.007)$ & $(0.007)$ & $(0.005)$ & $(0.009)$ & $(0.013)$ & $(0.005)$ & $(0.012)$ & $(0.010)$ & $(0.006)$ & $(0.013)$ & $(0.009)$ & $(0.010)$ & $(0.008)$ \\
\hline$\sum^{q-1} \pi_{j}^{+}$ & $\begin{array}{l}0.450 \\
(0.032)\end{array}$ & $\begin{array}{l}0.578 \\
(0.021)\end{array}$ & $\begin{array}{l}0.623 \\
(0.024)\end{array}$ & $\begin{array}{l}0.749 \\
(0.014)\end{array}$ & 0.431 & $\begin{array}{l}0.264 \\
(0.023)\end{array}$ & 0.617 & 0.873 & $\begin{array}{l}0.304 \\
(0.013)\end{array}$ & 0.365 & 0.460 & 0.282 & 0.401 & 0.916 \\
\hline & $\begin{array}{l}1.027 \\
0.436\end{array}$ & 0.567 & $\begin{array}{l}0.0244) \\
0.605\end{array}$ & 0.738 & 0.414 & $\begin{array}{l}(0.23) \\
0.253\end{array}$ & 0.607 & $\begin{array}{l}l .0344 \\
0.854\end{array}$ & 0.291 & 0.349 & $\begin{array}{l}0.445 \\
0.445\end{array}$ & $\begin{array}{l}(.018) \\
0.269\end{array}$ & $\begin{array}{l}(0.022) \\
0.389\end{array}$ & $\begin{array}{l}(0.033) \\
0.905\end{array}$ \\
\hline$\sum_{j=1} \pi_{j}^{-}$ & $(0.011)$ & $(0.012)$ & $(0.013)$ & $(0.015)$ & $(0.016)$ & $(0.007)$ & $(0.013)$ & $(0.007)$ & $(0.016)$ & $(0.014)$ & $(0.006)$ & $(0.007)$ & $(0.013)$ & $(0.011)$ \\
\hline \multirow{2}{*}{\multicolumn{15}{|c|}{$\begin{array}{l}0.0028 \\
(0.0009)\end{array}$}} \\
\hline & & & & & & & & & & & & & & \\
\hline$H_{0}: \alpha^{+}=\alpha^{-}$, using Dayes & 1749 & 1552 & 3624 & 2682 & 6479 & & $51=0$ & 6636 & 6555 & 1618 & 7025 & 1006 & 1095 & 3034 \\
\hline$H_{0}: \pi_{0}^{+}=\pi_{0}^{-}$ & 79.35 & 74.87 & 77.12 & $\begin{array}{l}03.89 \\
6392\end{array}$ & 48.47 & $\begin{array}{l}49.60 \\
62.13\end{array}$ & 55.54 & 75.07 & 82.85 & 48.42 & 56.93 & $\begin{array}{l}43.20 \\
61.86\end{array}$ & 8246 & $\begin{array}{l}30.34 \\
6275\end{array}$ \\
\hline$H_{0}: \sum_{j=1}^{q-1} \pi_{j}^{+}=\sum_{j=1}^{q-1} \pi_{j}^{-}$ & 63.81 & 67.13 & 78.63 & 54.51 & 81.56 & 89.40 & 55.89 & 79.92 & 77.36 & 54.87 & 84.70 & $\begin{array}{l}61.00 \\
68.64\end{array}$ & $\begin{array}{l}86.70 \\
86.75\end{array}$ & 73.13 \\
\hline \multicolumn{15}{|c|}{ Long-run relationship, using Bayes' Factor } \\
\hline & 120.6 & 83.99 & 95.33 & 96.17 & 125.2 & 131.8 & 138.7 & 87.51 & 131.82 & 79.61 & 100.7 & 110.7 & 154.8 & 104.3 \\
\hline$\rho=\delta^{+}=\delta^{-}$ & 241.0 & 248.5 & 218.7 & 245.8 & 209.8 & 190.8 & 254.7 & 179.5 & 205.1 & 251.8 & 194.2 & 184.1 & 195.0 & 190.1 \\
\hline
\end{tabular}

Notes: Estimated coefficients report posterior means and posterior standard deviations of the most important parameters of the model. 
Table B4: Milk, Cheese and Eggs: country specific model (2005:01-1016:09

\begin{tabular}{|c|c|c|c|c|c|c|c|c|c|c|}
\hline \multirow{2}{*}{\multicolumn{11}{|c|}{ Farm to Producer }} \\
\hline & & & & & & & & & & \\
\hline \multicolumn{11}{|l|}{ Estimated Coefficients } \\
\hline$\rho$ & $\begin{array}{l}-0.151 \\
(0.010)\end{array}$ & $\begin{array}{l}-0.184 \\
(0.005)\end{array}$ & $\begin{array}{l}-0.280 \\
(0.007)\end{array}$ & $\begin{array}{l}-0.192 \\
(0.005)\end{array}$ & $\begin{array}{l}-0.121 \\
(0.004)\end{array}$ & $\begin{array}{l}-0.266 \\
(0.003)\end{array}$ & $\begin{array}{l}-0.272 \\
(0.009)\end{array}$ & $\begin{array}{l}-0.278 \\
(0.004)\end{array}$ & $\begin{array}{l}-0.305 \\
(0.009)\end{array}$ & $\begin{array}{l}-0.065 \\
(0.010)\end{array}$ \\
\hline$\alpha^{+}$ & 1.114 & 1.137 & 1.022 & 0.979 & 0.872 & 0.830 & 1.032 & 1.056 & 1.015 & 0.885 \\
\hline & $(0.019)$ & $(0.013)$ & $(0.018)$ & $(0.019)$ & $(0.019)$ & $(0.015)$ & $(0.016)$ & $(0.019)$ & $(0.020)$ & $(0.021)$ \\
\hline$\alpha^{-}$ & 1.082 & 1.118 & 1.004 & 0.944 & 0.838 & 0.796 & 0.998 & 1.040 & 0.986 & 0.861 \\
\hline$\pi_{0}^{+}$ & $\begin{array}{l}(0.088) \\
0.433\end{array}$ & $\begin{array}{l}(0.006) \\
0.146\end{array}$ & $\begin{array}{l}(0.008) \\
0.29\end{array}$ & $\begin{array}{l}(0.008) \\
0.054\end{array}$ & $(0.010)$ & $(0.006)$ & $(0.010)$ & $(0.010)$ & $(0.006)$ & $(0.007)$ \\
\hline$\pi_{0}^{+}$ & $\begin{array}{l}0.433 \\
(0.011)\end{array}$ & $\begin{array}{l}0.146 \\
(0.006)\end{array}$ & $\begin{array}{l}0.229 \\
(0.012)\end{array}$ & $\begin{array}{l}0.354 \\
(0.013)\end{array}$ & $\begin{array}{l}0.490 \\
(0.012)\end{array}$ & $\begin{array}{l}0.374 \\
(0.006)\end{array}$ & & $\begin{array}{l}0.492 \\
(0.005)\end{array}$ & 0.252 & 0.314 \\
\hline$\pi_{0}^{-}$ & 0.414 & 0.136 & 0.215 & 0.339 & 0.470 & $0.360^{\circ}$ & 0.215 & & 0.237 & 0.299 \\
\hline & $(0.004)$ & $(0.004)$ & $(0.005)$ & $(0.004)$ & $(0.006)$ & $(0.003)$ & $(0.002)$ & $(0.005)$ & $(0.003)$ & $(0.002)$ \\
\hline$\sum_{i=1}^{q-1} \pi_{j}^{+}$ & $\begin{array}{l}0.524 \\
(0.021)\end{array}$ & $\begin{array}{l}0.282 \\
(0.020)\end{array}$ & $\begin{array}{l}0.475 \\
(0.032)\end{array}$ & $\begin{array}{l}0.459 \\
(0.031)\end{array}$ & $\begin{array}{l}0.254 \\
(0.029)\end{array}$ & $\begin{array}{l}0.584 \\
(0.013)\end{array}$ & $\begin{array}{l}0.368 \\
(0.027)\end{array}$ & $\begin{array}{l}0.508 \\
(0.030)\end{array}$ & $\begin{array}{l}0.723 \\
(0.015)\end{array}$ & $\begin{array}{l}0.833 \\
(0.030)\end{array}$ \\
\hline$\sum^{q-1} \pi^{-}$ & 0.507 & 0.264 & 0.458 & 0.441 & 0.242 & 0.566 & 0.357 & 0.490 & 0.708 & 0.821 \\
\hline$\sum_{j=1} \pi_{j}$ & $(0.015)$ & $(0.013)$ & $(0.016)$ & $(0.014)$ & $(0.009)$ & $(0.015)$ & $(0.013)$ & $(0.007)$ & $(0.015)$ & $(0.007)$ \\
\hline$\lambda$ & & & & & $\begin{array}{l}0.007 \\
(0.000\end{array}$ & & & & & \\
\hline \multicolumn{11}{|c|}{ Symmetry tests, using Bayes' Factor } \\
\hline$H_{0}: \alpha^{+}=\alpha^{-}$ & 58.93 & 31.46 & 17.25 & 57.99 & 20.20 & 26.10 & 57.75 & 12.91 & 16.98 & 32.63 \\
\hline$H_{0}: \pi_{0}^{+}=\pi_{0}^{-}$ & 114.3 & 84.92 & 54.64 & 83.83 & 80.43 & 174.9 & 114.7 & 61.46 & 127.5 & 138.9 \\
\hline$H_{0}: \sum_{j=1}^{q-1} \pi_{j}^{+}=\sum_{j=1}^{q-1} \pi_{j}^{-}$ & 54.50 & 112.3 & 58.02 & 60.59 & 104.2 & 105.3 & 72.78 & 114.1 & 117.0 & 80.63 \\
\hline \multirow{2}{*}{\multicolumn{11}{|c|}{ Long-run relationship, using Bayes' Factor }} \\
\hline$\rho=0$ & & & 141.0 & 112.8 & 120.9 & 127.1 & 86.69 & 106.2 & 80.18 & 131.7 \\
\hline$\rho=\delta^{+}=\delta^{-}$ & 183.0 & 209.2 & 194.5 & 201.7 & 234.7 & 215.9 & 199.4 & 234.7 & 226.5 & 212.8 \\
\hline \multirow{2}{*}{\multicolumn{11}{|c|}{ Producer to Consumer }} \\
\hline & & & & & & & & & & \\
\hline$\rho$ & -0.282 & -0.216 & -0.348 & -0.344 & -0.213 & -0.134 & -0.257 & -0.190 & -0.320 & -0.118 \\
\hline & $(0.005)$ & $(0.009)$ & $(0.009)$ & $(0.003)$ & $(0.009)$ & $(0.006)$ & $(0.005$ & $(0.004)$ & $(0.004)$ & $(0.006)$ \\
\hline$\alpha^{+}$ & $\begin{array}{l}0.954 \\
(0.013)\end{array}$ & $\begin{array}{l}0.941 \\
(0.020)\end{array}$ & $\begin{array}{l}1.146 \\
(0.017)\end{array}$ & $\begin{array}{l}0.893 \\
(0.015)\end{array}$ & $\begin{array}{l}1.031 \\
(0.018)\end{array}$ & $\begin{array}{l}0.947 \\
(0.016)\end{array}$ & $\begin{array}{l}0.872 \\
(0.014)\end{array}$ & $\begin{array}{l}1.020 \\
(0.016)\end{array}$ & 1.017 & 0.953 \\
\hline$\alpha^{-}$ & 0.933 & 0.907 & $\begin{array}{l}(0.011) \\
1.118\end{array}$ & $\begin{array}{l}(0.015) \\
0.861\end{array}$ & $\begin{array}{l}(0.018) \\
1.008\end{array}$ & $\begin{array}{l}(0.016) \\
0.925\end{array}$ & $\begin{array}{l}(0.014) \\
0.839\end{array}$ & $(0.016)$ & $(0.014)$ & $\begin{array}{l}(0.021) \\
0.921\end{array}$ \\
\hline$a$ & $\begin{array}{l}(0.008) \\
(0.008)\end{array}$ & $(0.008)$ & $(0.006)$ & $\begin{array}{l}(0.009) \\
(0.09\end{array}$ & $(0.007)$ & $(0.006)$ & $(0.006)$ & $\begin{array}{l}(0.010) \\
(0.04\end{array}$ & $\begin{array}{l}0.989 \\
(0.008)\end{array}$ & $\begin{array}{l}0.921 \\
(0.008)\end{array}$ \\
\hline$\pi_{0}^{+}$ & 0.424 & 0.245 & 0.431 & 0.403 & 0.336 & 0.441 & 0.306 & 0.336 & 0.269 & 0.389 \\
\hline & $(0.010)$ & $(0.009)$ & $(0.005)$ & $(0.013)$ & $(0.007)$ & $(0.012)$ & $(0.008)$ & $(0.011)$ & $(0.008)$ & $(0.008)$ \\
\hline$\pi_{0}^{-}$ & 0.405 & 0.228 & 0.420 & 0.383 & 0.319 & 0.424 & 0.286 & 0.325 & 0.252 & 0.370 \\
\hline & $(0.006)$ & $(0.004)$ & $(0.003)$ & $(0.002)$ & $(0.004)$ & $(0.002)$ & $(0.003)$ & $(0.003)$ & $(0.003)$ & $(0.002)$ \\
\hline$\sum_{\pi_{i}^{+}-1}^{q-1}$ & 0.329 & 0.535 & 0.421 & 0.517 & 0.217 & 0.722 & 0.554 & 0.436 & 0.685 & 0.338 \\
\hline$L_{j=1} n_{j}$ & $(0.017)$ & $(0.019)$ & $(0.024)$ & $(0.030)$ & $(0.017)$ & $(0.028)$ & $(0.028)$ & $(0.021)$ & $(0.026)$ & $(0.026)$ \\
\hline$\sum_{i=1}^{q-1} \pi_{j}^{-}$ & 0.311 & $\begin{array}{l}0.522 \\
(0.011)\end{array}$ & 0.408 & $\begin{array}{l}0.504 \\
(0.009)\end{array}$ & $\begin{array}{l}0.199 \\
(0.007)\end{array}$ & $\begin{array}{l}0.710 \\
(0.009)\end{array}$ & 0.538 & $\begin{array}{l}0.423 \\
0.017)\end{array}$ & $\begin{array}{l}0.673 \\
0.015)\end{array}$ & $\begin{array}{l}0.322 \\
(0.014)\end{array}$ \\
\hline$\lambda^{{ }_{j=1}}$ & & & & & 0.003 & $(0.009)$ & $(0.006)$ & & $(0.015)$ & \\
\hline & & & & & $(0.000$ & & & & & \\
\hline \multicolumn{11}{|c|}{ Symmetry tests, using Bayes' Factor } \\
\hline$H_{0}: \alpha^{+}=\alpha^{-}$ & 15.23 & 65.97 & 22.59 & 27.06 & 15.66 & 63.17 & 32.86 & 21.70 & 21.19 & 63.36 \\
\hline$H_{0}: \pi_{0}^{+}=\pi_{0}^{-}$ & 155.2 & 108.9 & 71.59 & 52.77 & 101.56 & 82.66 & 171.3 & 105.0 & 87.89 & 180.2 \\
\hline$H_{0}: \sum_{j=1}^{q-1} \pi_{j}^{+}=\sum_{j=1}^{q-1} \pi_{j}^{-}$ & 102.3 & 121.3 & 81.26 & 84.48 & 98.49 & 55.93 & 108.7 & 81.39 & 66.55 & 89.13 \\
\hline \multicolumn{11}{|c|}{ Long--un relationship, using Bayes' Factor } \\
\hline & 110.6 & 114.1 & 109.6 & 153.6 & 118.4 & 148.4 & 118.8 & 134.9 & 106.3 & 118.6 \\
\hline$\rho=\delta^{+}=\delta^{-}$ & 194.6 & 237.2 & 248.9 & 254.7 & 218.8 & 231.9 & 220.0 & 250.7 & 235.2 & 219.4 \\
\hline
\end{tabular}

Notes: Estimated coefficients report posterior means and posterior standard deviations of the most important parameters of the model. 
Table B5: Oils and Fats: country specific model (2005:01-1016:09)

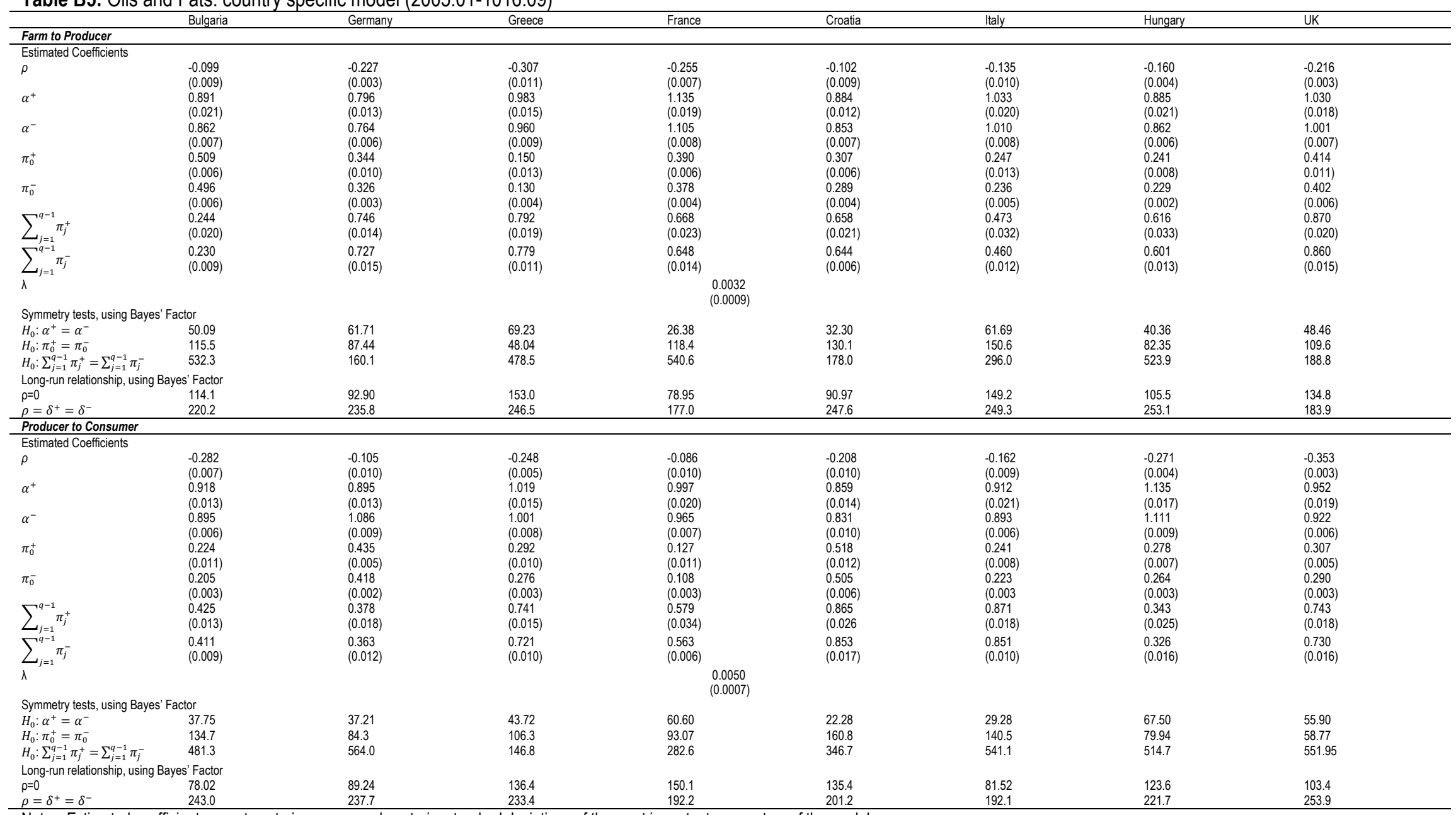

Notes: Estimated coefficients report posterior means and posterior standard deviations of the most important parameters of the model. 
